University of Miami Law School

University of Miami School of Law Institutional Repository

1989

The New Economic Theory of the Firm: Critical Perspectives from History

William Wilson Bratton

Follow this and additional works at: https://repository.law.miami.edu/fac_articles

Part of the Law Commons 


\title{
The New Economic Theory of the Firm: Critical Perspectives from History
}

\author{
William W. Bratton, Jr.*
}

\section{INTRODUCTION}

Theories of the firm inform and undergird corporate law, ${ }^{1}$ but they only intermittently appear as principal points in corporate law discourse. They stayed in the background during the half century ending in 1980, while a conception of the firm as a management power structure prevailed unchallenged in legal theory. ${ }^{2}$ The situation changed around 1980, when a new theory of the firm ${ }^{3}$ appeared, imported from economics. This "new economic theory of the firm" asserted a contractual conception. The firm, said its leading text, is a legal fiction that serves as a nexus for a set of contractual relationships among individual factors of production. ${ }^{4}$ According to the theory, corporate relationships and structures could be explained in terms of contracting parties and transaction costs. Law and economics writers restated corporate law in the new theory's terms ${ }^{5}$ and successfully reoriented legal discourse on corporations. ${ }^{6}$ The new theory already has sunk into the

* Professor of Law, Benjamin N. Cardozo School of Law, Yeshiva University. My thanks to Victor Brudney, Drucilla Cornell, Stephen Diamond, Michael Piore, Paul Shupack, Katherine Van Wezel Stone, David Sugarman, Peter Temin, Willam Wang, Elliott Weiss, and Charles Yablon for their comments on an earlier draft of this paper, and to Alan Baral and Joseph Tomkiewicz for research assistance. I am grateful for the support of the Samuel and Ronnie Heyman Corporate Governance Program of the Cardozo Law School.

1. Economic theories of the firm concern all producing units, no matter how organized. Legal theories of the firm, in contrast, tend to focus on the corporation.

2. See notes 18-21 infra and accompanying text.

3. The theory's proponents refer to it as the "modern" theory of the firm. I use "new" theory of the firm for two reasons. First, as this article's historical exposition demonstrates, the ideas constituting the theory are not modern. However, the particular configuration is new both to microeconomics and to corporate law. Second, at least one opponent of the new economic theory claims the mantle of modernity for corporate law reform proposals criticized by proponents of the new economic theory. See Melvin Aron Eisenberg, New Modes of Discourse in the Corporate Law Literature, 52 Geo. WASH. L. REv. 582, 582 (1984).

4. Michael C. Jensen \& William H. Meckling, Theory of the Firm: Managerial Behavior, Agency Costs and Ownership Siructure, 3 J. FIN. EcoN. 305, 310 (1976). For literal restatements of this in the legal literature, see, for example, Robert Hessen, $A$ New Concept of Corporations: $A$ Contractual and Private Property Model, 30 Hastings L.J. 1327, 1330 (1979); Reinier H. Kraakman, Corporate Liability Strategies and the Costs of Legal Controls, 93 YALE L.J. 857, 862 (1984); Kenneth E. Scott, Corporation Law and the American Law Institute Corporate Governance Project, 35 STAN. L. REv. 927, 930 (1983).

5. For a survey, see text accompanying notes 22-26 infra.

6. See note 22 infra. 
fabric of academic corporate law. ${ }^{7}$ Now we have two paradigms, one managerialist, the other contractual.

The new theory's proponents made strong claims on its behalf. The economists who originated it proclaimed a major discovery: Professor -Michael Jensen, for example, predicted that this infant "science of organizations" will produce a "revolution . . . in our knowledge about organizations" during "the next decade or two ...."8 In the law schools, its enthusiasts moved aggressively for equal academic status (including representation among the drafters of the American Law Institute's Corporate Governance Project). ${ }^{9}$ Even outside observers expressed enthusiasm about the new perspective's potential. Professor Bruce Ackerman saw "the stage ... being set for a complex, yet broadbased analysis of the way in which activist law, by controlling the legal forms provided to the parties, can shape the way they use their legal freedom to plan their activities." 10

Employing historical analysis, this article disputes these claims. History contains essential information about theories of the firm: ${ }^{11}$ Lawyers and economists have formulated principles to describe and regulate the relationship between individuals and producing institutions on repeated past occasions. ${ }^{12}$ This article recounts these exercises in American corporate legal history, fitting the new economic theory into the resulting pattern.

Once seen in historical context, the theory loses the revolutionary impact claimed by its proponents. It constitutes a significant innovation in neoclassical microeconomic theory. But, outside that limited methodological context, it is merely the latest in a long series of attempts to describe and justify the phenomenon of collective production

7. A recent round of discussion on takeovers demonstrates this, assuming contractualism without applying the theory formally. See Jeffrey N. Gordon \& Lewis A. Kornhauser, Takeover Defense Tactics: A Comment on Two Models, 96 YALE L.J. 295 (1986); Jonathan R. Macey \&Fred S. McChesney, A Theoretical Analysis of Corporate Greenmail, 95 YALE L.J. 13 (1985).

8. Michael C. Jensen, Organization Theory and Methodology, 58 AccT. Rev. 319, 324 (1983). Professor Jensen is one of the originators and masters of the new theory.

9. Judge Ralph Winter attacks the American Law Institute Corporate Governance Project because the new economic theory, a "large body of reputable academic opinion in major law schools," is "astonishingly unrepresented" among its drafters. Ralph $\mathrm{K}$. Winter, Jr., The Development of the Law of Corporate Governance, 9 DEL. J. CoRP. L. 524, 528-29 (1984).

10. Bruce A. Ackerman, Reconstructing American Law 62 (1984). Ackerman's "activist" seeks to use the law "to design a better form of accommodation between competing activities than the one thrown up by the invisible hand." Id. at 31 . Ackerman's statist perspective contrasts sharply with the anti-statism that prevails throughout the economic literature of the new theory of the firm. See text accompanying note 17 infra.

11. History rarely tends to be pursued in corporate law contexts. Usually this has no ill effect, since lack of historical perspective only trivially impairs discussion of the latest technical regulatory problems. As the context of discussion becomes wider, however, relentlessly ahistorical perspectives become limiting and damaging.

12. Historical information is particularly useful in the evaluation of the new economic theory. Many of the theory's basic conceptual elements-for example, classical economic assumptions, political individualism, and antipositivism-have figured into past legal theories of the firm. 
in individualist terms. Such theories have followed from and responded to economic practice; they have not dominated and determined it.

History also shows that contract always has held a constitutive place in corporate legal theory. This helps explain the new theory's success in the law. Its microeconomic innovations resonate well because they reconfirm and highlight antecedent concepts. However, history also suggests that the new theory goes too far in demanding that corporate law privilege contract. Historically, contract has had an equal, or more often subordinate, position in corporate legal theory-a position closely grounded in and responsive to economic practice. Changes in economic practice during the past two decades, while substantial, have not been so fundamental as to mandate that corporate law become absolutely contractual.

These recent changes in economic practice have played a role in the new theory's appearance. Taking the theory as a phenomenon in history, this article demonstrates that particular economic and legal practices of the 1960s and 1970s enabled the new theory's formulation. The theory, thus viewed, becomes an academic by-product of practical changes in the governance of the management corporation. ${ }^{13}$ It stems from and follows the events, repeating time-honored concepts about large-scale production in a form responsive to contemporary ways of doing business. Thus bound to history, it seems a vehicle unsuited to the control and reconstruction of legal practice.

This article has five parts. Part I describes basic concepts. It sets out the elements of traditional legal theories of the firm, managerialism, and the new economic theory. Part II sets out a history of theory of the firm concepts in American corporate legal theory. This history relates economic, institutional, and doctrinal changes to changes in theories of the firm. More particularly, the account centers on the appearance, success, and endurance of the management corporation in the late nineteenth and early twentieth centuries and corresponding developments in corporate doctrine. It shows how these practical events caused the reformulation of traditional legal theories of the firm and shaped the long-prevalent managerialist conception of the corporation. The account emphasizes an ongoing conflict between practical developments and the theorists' political preferences. Production by corporate entities-a collective phenomenon-conflicted with these theorists' individualistic assumptions about society and economics. The theories, succeeding one another in history, embody variant solutions to this conflict.

Part III sets out a parallel history of the theory of the firm in corpo-

13. I employ the phrase "management corporation" rather than "public corporation" to describe large mass-producing corporations and other large corporate entities, the shares of which are widely held. 
rate legal doctrine. This account isolates the theory of the firm concepts underlying the doctrine. Here, in contrast to the theoretical evolution described in part II, the story is nonevolutionary. The concepts instantiated in the doctrine have persisted with notable stability from the mid-nineteenth century to the present. This contrasting pattern follows from its different context. Theoretical tensions between individualistic values and collective production do not concern legal practitioners. These lawyers, judges, and legislators employ a capacious firm theory, sidestepping theoretical conflicts and resolving conflicts between individual autonomy and production imperatives piecemeal, on the level of the particular.

Part IV is a commentary. It relates the histories to the contemporary contest between managerialism and the new economic theory. It suggests that historically dominant concepts still inform the law, limiting the potential influence of the new theory. This part also comments on the thesis recently advanced by Professor Morton Horwitz that the theory of the firm played a causative role in the success of the management corporation at the turn of the century. ${ }^{14}$ Horwitz's thesis, it is argued, is untenable in light of the nonevolutionary path of the doctrinal theory of the firm identified in this article.

Part V analyzes the new economic theory as an event in contemporary history. It relates the theory's appearance and success to practical developments concerning the management corporation. It suggests that the theory would never have existed had finance capitalism not become a force in corporate governance through the operation of the market for corporate control.

\section{Legal Theories of the Corporate Firm and the New ECONOMIC THEORY}

This part sets out the concepts basic to discourse on corporate legal theory, both historical and contemporary. First, it describes the recurring questions that legal theories of the firm traditionally address-concepts central to this article's historical accounts. Then it introduces concepts informing discourse on the theory of the firm today. It describes the managerialist conception of the corporation that prevailed when the new economic theory of the firm appeared in legal theory around 1980. Then it describes the new economic theory as set forth in the economics literature in the 1970s and early 1980s.

\section{A. Traditional Legal Theories of the Corporate Firm}

Traditional legal theories of the corporation ${ }^{15}$ pursue an essentialist

14. Morton J. Horwitz, Santa Clara Revisited: The Development of Corporale Theory, $88 \mathrm{WV}$. VA. L. REv. 173, 176 (1985).

15. Traditional legal theories of the corporation were a recognizable category of juris- 
inquiry into the corporation's nature and origins. ${ }^{16}$ This inquiry, whether academic or doctrinal, dwells on sets of recurring questions.

One set of questions asks about the corporation's being. Here one line of responses holds the corporation to be at most a reification-a construction of the minds of the persons connected with the firm and those who deal with them and their products. A conflicting line holds the corporate firm to be a real thing having an existence, like a spiritual being, apart from the separate existences of the persons connected with it.

A related set of questions looks into distinctions between the corporate entity (whether real or reified) and the aggregate of separate individuals and transactions in and around it. This is the "entity or aggregate" discussion. It concerns the placement of emphasis between the group and the individual. If the corporate entity has a cognizable existence, questions arise about the nature and origins of its separate characteristics. Here personification-the attribution of human characteristics-provides a metaphorical mode of isolating components of the entity's essence. On the other hand, if the notion of an entity lacks meaning, the nature and origins of the corporation are determined by the relationship of its aggregate parts. Historically, observers taking this latter view characterize corporate life as contractual.

There also is a political version of this essentialist inquiry into the corporation's nature and origins. Here the basic question is whether the corporation must derive positive authority from the state. The statist response is called concession theory; the contrary view is called contractual. Concession theory comes in degrees. ${ }^{17} \mathrm{~A}$ strong version attributes the corporation's very existence to state sponsorship. A weaker version sets up state permission as a regulatory prerequisite to doing business. The contractual response locates the source of all firms' economic energy in individuals. Stated most strongly, this view holds that the individuals' freedom of contract implies a right to do business as a corporation without state interference. A variant of this discussion suggests that the corporation is not a suitable subject for regulation because its activities have a "private" rather than a "public" nature.

\section{B. Managerialism}

Speculation about the reality of corporations, their entity and aggregate characteristics, and their origins in concession or contract was commonplace in legal theory until around 1930. At that time, dis-

prudence and a focal point of legal theory until around 1930. See text accompanying notes 8293 infra.

16. For a description of the essentialist approach, see note 146 infra.

17. See William W. Bratton, The "Nexzs of Contracts" Corporation: $A$ Critical Appraisal, 74 Cornell L. Rev. (1989) (forthcoming). 
course in these terms largely ceased as the management-centered conception of large corporate entities took hold. ${ }^{18}$ The managerialist consensus recently disappeared, due in part to the successful emergence of the new economic theory in the legal literature beginning around 1980.

The managerialist picture put corporate management groups at the large corporation's strategic center. ${ }^{19}$ Management possessed hierarchical power. This structural power, stemming from their expertise in organizing resources, had three aspects. First, management determined the processes of production and distribution. Second, management dominated enormous bureaucracies and exercised authority over the lives of all those lower down on the ladder. Third, managementdominated firms imposed externalities. ${ }^{20}$

This picture's accuracy was not an issue in corporate law. All participants, pro- or anti-managerialist, saw the firm as a "structure." All agreed that the structure gave rise to power relationships and that management dominated the structure. The issue was whether management held and exercised the power legitimately. Anti-managerialists charged that management exercised its power without accountability. This argument had three parts. First, legal doctrine vested governing power of the corporate entity in the board of directors subject to shareholder vote. Second, management in fact controlled the board. And third, the financial community supported management. Therefore, management groups were unaccountable to higher authority. Management's defenders countered with a two-part defense. First came utility-expertise legitimized management authority. Then followed assurances of social responsibility-managers were capable of statesmanship. ${ }^{21}$

\section{The New Economic Theory of the Firm}

Economists devised the new economic theory during the 1970s. It appeared in corporate legal theory, achieving wide currency and acceptance, after 1980.22 The theory challenged the managerialist pic-

18. See text accompanying notes 104-110 infra.

19. For a further discussion, see Bratton, supra note 17.

20. For exemplars of this picture, see Adolf A. Berle, Jr., The 20th Century Capitalist Revolution 32-39 (1954); Ralph Nader, Mark Green \& Joel Seligman, Taming the Giant Corporation 62-65 (1976).

21. See Gerald E. Frug, The Ideology of Bureaucracy in American Law, 97 Harv. L. Rev. 1276, 1328-34 (1984).

Berle worked both sides of the fence. While anti-managerialist, he eventually conceded that public opinion effectively controlled management and optimistically preached responsibility to the managerial audience. See A. BerLe, supra note 20, at 35-37, 54.

22. See, e.g., Barry D. Baysinger \& Henry N. Butler, Revolution Versus Evolution in Corporation Law: The ALI's Project and the Independent Director, 52 GEo. WASH. L. REV. 557 (1984); Lucian Arye Bebchuk, Limiting Contractual Freedom in Corporate Law: The Desirable Constraints on Charter "Amendments, 102 HaRv. L. Rev. 1820 (1989); Frank H. Easterbrook \& Daniel R. Fischel, Close Corporations and Agency Costs, 38 STAN. L. Rev, 271 (1986); Frank H. Easterbrook \& Daniel R. Fischel, Limited Liability and the Corporation, 52 U. CHI. L. REv. 89 (1985); Frank H. Easterbrook \& Daniel R. Fischel, Voting in Corporate Law, 26 J.L. \& EcoN. 395 (1983); Frank H. Easterbrook 
ture of the corporation and prompted renewed concern about the nature of the corporation among legal academics. Once again entities and aggregates, and concessions and contracts, appeared in corporate law discourse.

The new economic theory has two variants, one strong, the other weak. The strong variant has antecedents in neoclassical economics; the weak variant has closer ties to institutional economics.

The institutional variant appeared first. Its earliest antecedent is an essay Ronald Coase published in 1937. Coase explained firms and markets as alternative forms of contracting, identifying transaction costs as the determinants of the choice between the two. ${ }^{23}$ This work, while seminal, had no noticeable influence among neoclassical economists until after 1970.24 Even then, Coase's distinction between markets and firm hierarchies only influenced the institutionalists, who restate the received managerialist picture in contractual terms.

We can precisely date the advent of the neoclassical variant with the publication of a paper by Alchian and Demsetz in 1972.25 The watershed year was 1976, when Jensen and Meckling's well-known analysis of the firm appeared. ${ }^{26}$ These papers draw on neoclassical conceptions of contract to devise a radical rejection of the managerialist approach.

The following describes the two variants, taking the neoclassical rendering first. ${ }^{27}$

\& Daniel R. Fischel, Corporate Control Transactions, 91 Yale L.J. 698 (1982); Daniel R. Fischel, The Appraisal Remedy in Corporate Law, 1983 AM. B. Found. REs. J. 875; Daniel R. Fischel, The Corporate Governance Movement, 35 VAND. L. REv. 1259 (1982); Ronald J. Gilson, Evaluating Dual Class Common Stock: The Relevance of Substitutes, 73 VA. L. REv. 807, 808-11 (1987); Kraakman, supra note 4; Saul Levmore, Monitors and Freeriders in Commercial and Corporate Settings, 92 YALE L.J. 49 (1982); Jonathan R. Macey, From Faimess to Contract: The New Direction of the Rules Against Insider Trading, 13 HofsTra L. REv. 9, 39-47 (1984); Scott, supra note 4.

Critical commentaries have appeared. See Victor Brudney, Corporate Governance, Agency Costs, and the Rhetoric of Contract, 85 Colum. L. REv. 1403 (1985); Richard M. Buxbaum, Corporate Legitimacy, Economic Theory, and Legal Doctrine, 45 OHIo ST. L.J. 515 (1984); Robert C. Clark, Agency Costs l'etsus Fiducian' Duties, in Principals and Agents: The Structure of Business 55 (J. Pratt \& R. Zeckhauser eds. 1985); Deborah A. DeMott, Beyond Metaphor: An Analysis of Fiduciary Obligation, 1988 DuKe L.J. 879.

23. See Ronald H. Coase, The Nature of the Firm, 4 Economica 386, 390-94 (1937) (reprinted in Readings in Price Theory 331, 336-39 (G. Stigler \& K. Boulding eds. 1952)).

24. Coase reflected in 1972 that his 1937 essay was "much cited but little used." Ronald H. Coase, Industrial Organization: A Proposal for Research, 3 Economic Research: ReTrospect And Prospect 59, 62-63 (V. Fuchs ed. 1972); see also Ronald H. Coase, The Nature of the Firm: Meaning, 4 J.L. Econ. \& ORG. 19, 23 (1988).

Other early work came from Oliver Williamson. See Oliver E. Williamson, Managerial Discretion and Business Behavior, 53 AM. EcoN. Rev. 1032 (1963).

25. Armen A. Alchian \& Harold Demsetz, Production, Information Costs, and Economic Organization, 62 AM. ECON. REv. 777 (1972).

26. Jensen \& Meckling, supra note 4. An important contemporaneous work was Oliver E. Williamson, Markets and Hierarchies: Analysis and Antitrust Implications (1975). Other early works include KenNETH J. ARROw, The Limits of Organization (1974); Vernon L. Smith, Economic Theory and its Discontents, 64 AM. Econ. Rev. 320 (1974).

Anti-managerialists dominated legal discourse during these years. For example, see William L. Cary, Federalism and Corporate Law: Reflections upon Delaware, 83 YALE L.J. 663 (1974).

27. For a further discussion, see Bratton, supra note 17. 


\section{The neoclassical variant.}

The neoclassical variant's central point is that the firm is a legal fiction that serves as a nexus for a set of contracting relations among individual factors of production. ${ }^{28}$ Applied to corporations, this assertion displaces the management centered conception. The firm, taken as a neoclassical contracting nexus, is not necessarily a hierarchy in which authority determines terms by fiat. As Alchian and Demsetz said in their 1972 article, firms have "no power of fiat, no authority, no disciplinary action." They do not differ "in the slightest degree from ordinary market contracting between any two people." The neoclassical variant reconceives management as a continuous process of negotiation of successive contracts. The dissatisfied party always can terminate its dealings with the firm. ${ }^{29}$

From this starting point, the neoclassical theorists construct a model of the management corporation. They find parties and terms for their firm of contracts by drawing on economists' basic assumptions about the behavior of marketplace actors and the nature of marketplace contracts. The actors are rational economic actors ${ }^{30}$ - self-interested individuals with divergent interests. ${ }^{31}$ The contracts are the equilibrium contracts that rational economic actors enter into when dealing in markets $^{32}$-instantaneous exchanges between maximizing parties. The parties make complete choices, dealing with unknown factors in the exchange price. ${ }^{33}$ The theorists further assume that effective competition exists among the contracting parties. They also apply the principle of natural selection. That is, rational economic actors, consciously or not, solve problems in the process of pursuing wealth maximization. Given the actors' capabilities and intense competition, only optimal contracting strategies survive. ${ }^{34}$

Within this framework, firm contracts take forms determined by the now well known imperative of agency. cost reduction. The process works as follows. Risk-allocating contracts have winners and losers.

28. This formulation draws on the original language of Jensen \& Meckling, supra note 4, at 310; see also Eugene F. Fama \& Michael C. Jensen, Separation of Ownership and Control, 26 J.L. \& EcoN. 301, 302 (1983); Jensen, supra note 8, at 326. In the legal literature, see, e.g., Fischel, The Corporate Governance Movement, supra note 22, at 1261-62; Scott, supra note 4, at 930.

29. See Alchian \& Demsetz, supra note 25, at 777; see also id. at 794. In another essay, Demsetz admits that there are some people who derive utility from coercive relationships, but he cites only bullies and rapists as exemplars of the type. Harold Demsetz, Professor Michelman's Unnecessary and Futile Search for the Philosopher's Touchstone, in 24 Nomos: ErHIcs, ECONOMICS AND THE LAW 41, 44 (1982). (1980).

30. Eugene F. Fama, Agency Problems and the Theory of the Firm, 88 J. PoL. Econ. 288, 289

31. See Jensen, supra note 8, at 331; William H. Meckling, Values and the Choice of Method in the Social Sciences, 112 SchwEIZERISCHE ZEITSCHRIFT FUER VOLKWIRTSCHAFT UND STATISTIK 545, $548-49$ (1976).

32. See Jensen, supra note 8, at 327.

33. See Ian R. Macneil, Economic Analysis of Contractual Relations: Its Shortfalls and the Need for a "Rich Classificatory Apparatus," 75 Nw. U.L. REv. 1018, 1022-23, 1039-40 (1981).

34. Jensen, supra note 8 , at $322,327$. 
Maximizing losers tend to "shirk"- that is, take actions to avoid having to perform their promises fully. Agency costs are the costs of shirking. Since rational economic actors know about shirking, they charge agency costs against their contracting partners ahead of time. Given competition, the party who most reduces agency costs has the edge. Again, applying the principle of natural selection, the lowest cost contract forms survive. ${ }^{35}$

With this model the theorists have rationalized, inter alia, the positive law of relations among shareholders, boards of directors, and officers; the internal decisionmaking structures, policies, and procedures of corporate bureaucracies; and the contracts firms make with employees, suppliers, and creditors. Jensen and Meckling set out the basic themes. Managers act as agents to shareholder principals. When securities are sold publicly by management groups to outside shareholder principals, the purchasing shareholders assume that the managers will maximize their own welfare; the purchasers therefore bid down the price of the securities accordingly. Management thereby bears the costs of its own misconduct and has an incentive to control its own behavior. ${ }^{36}$ It achieves self-control, increasing the selling price of its securities by offering monitoring devices. These include common features of the corporate landscape such as independent directors and accountants, and legal rules against self-dealing. ${ }^{37}$ Subsequent essays from within the school expand the picture, pointing out that pressures from the management labor market ${ }^{38}$ and the market for corporate control also impel management to reduce agency costs. The received

35. See, e.g., Jensen, supra note 8 , at 331 ; Fama \& Jensen, supra note 28 , at 301 .

36. In the Jensen and Meckling model, the public sale is a secondary offering by the management group. In more complex, real world situations, the incentive is less intense.

37. This story, see Jensen \& Meckling, supra note 4, at 314, has been often repeated in the law reviews. See, e.g., Fischel, The Corporate Governance Movement, supra note 22, at 1262-65.

Preceding Jensen and Meckling, Alchian \& Demsetz, supra note 25, also explained corporate structure in terms of agency costs. But it painted a somewhat different picture. Jensen and Meckling took a governance perspective. They built their model around a hypothetical close corporation situation in which an owner management group sells equity to outsiders. Alchian and Demsetz emphasized the production process, focusing on shirking problems among individuals on production teams. The existence of management groups is explained as a function of shirking by input factors. Monitors (managers) must be accorded power to observe, but further arrangements are necessary since managers themselves will shirk. Residual income shares reduce this incentive. See Alchian \& Demsetz, supra note 25, at 781$82,787-88$.

Jensen and Meckling criticized this picture as too narrowly focused. See Jensen \& Meckling, supra note 4, at 310 . Interestingly, the Alchian and Demsetz picture has been repeated in eclectic law review commentary subsequent to the Jensen and Meckling repudiation of it. See Scott, supra note 4, at 930-31; Ralph K. Winter, Jr., State Law, Shareholder Protection, and the Theory of the Corporation, $6 \mathrm{~J}$. LEGAL STUD. 251, 272-73 (1977).

38. For the suggestion that management labor markets provide the primary discipline, see Fama, supra note 30, at 294-95. This is disputed in Benjamin Klein, Contracting Costs and Residual Claims: The Separation of Ownership and Control, 26 J.L. \& Econ. 367, 368 (1983), which takes the position that wage discounts cannot be taken into account in wage contracts $e x$ ante. For criticism of Fama's point that junior managers can be expected to monitor senior managers, see Eisenberg, supra note 3, at 584. 
division of authority between officers and board is explained in terms of low-cost information flow. ${ }^{39}$

This picture's implications become apparent if we contrast it with the earlier managerialist picture. The managerialist picture set out a structure and placed management at the top in a position of power. Pro-managerialists asserted that expertise necessitated this; antimanagerialists asserted that the power arose due to the absence of market constraints. The neoclassical new economic theory brings market constraints back into the picture. The discipline of price competition in the product market is accompanied by pricing disciplines from the markets for corporate securities and the markets for managers and other labor. The firm springs out of contracts in all of these markets. Since the contracts are bilateral, management power and corporate hierarchy, as previously conceived, disappear. In a firm of bilateral contracts between free market actors, both parties possess equal power to contract someplace else.

The neoclassical picture also implies a limited role for corporate law. Corporate law does not invest and legitimize power in hierarchical superiors; instead, it appears as just another term of the contract governing equity capital input. Given the model's basic assumption that the fittest arrangements survive, the contract presumably effects an optimal sharing of risk. ${ }^{40}$ The model, then, affords no basis for intervention by government for the protection of shareholders.

\section{The institutional variant.}

The institutional variant, like the neoclassical variant, announces that the firm is contract. However, noteworthy differences distinguish this approach. First, the institutionalists grant that the firm exists as a single maximizing unit, not simply as an artifact of transactions among maximizing individuals. ${ }^{41}$ While comprised of contracts, this firm entity amounts to a hierarchy. It is a "governance structure," distinguishable in a meaningful way from market contracting. ${ }^{42}$ Following Coase, the institutionalists inquire into differences between market and firm organization.

Second, the institutionalists assume an economic actor possessing a wider repertoire of human traits than does neoclassical economic man. Specifically, the institutional contracting party suffers from "bounded rationality" and engages in "opportunistic conduct." 43 The former re-

39. See Fama \& Jensen, supra note 28 , at 302-05.

40. Klein, supra note 38 , at 370 .

41. See Macneil, supra note 33, at 1022-23.

42. See Oliver E. Williamson, The Modern Corporation: Origins, Evolution, Attributes, $19 \mathrm{~J}$. ECON. LIT. 1537 (1981). Williamson sees the distinction between the firm and the market as a matter of degree. See Oliver E. Williamson, Intellectual Foundations: The Need for a Broader Vieus, 33 J. Legal Educ. 210, 214 (1983).

43. See Williamson, The Modern Corporation: Origins, Evolution, Attributes, supra note 42, at 1544-45 (using "opportunism" for "opportunistic conduct"). 
fers to an actor's limited ability to solve problems and process information. Bounded rationality prevents the institutionalist actor from achieving the neoclassical actor's concrete risk analysis and from making complete choices. Opportunistic conduct goes beyond the neoclassical actor's self-interested maximization to "guile"-behavior a lawyer would term "culpable."

These human failings inform the institutionalist picture of the firm contracting process. The parties know that they cannot achieve complete exchanges in all situations. They therefore leave terms open and consent to structures and processes to govern the relationship's future. ${ }^{44}$ Parties choose these "governance structures" over market exchanges where, for example, one or both parties' performance requires a transaction-specific investment susceptible to appropriation by the other. The parties design a transactional structure to prevent appropriation. Firm organization, along with most other forms of long-term contracting, is one of these transactional structures. ${ }^{45}$

Many other matters affect the institutionalists' transaction structures. Some, such as free rider problems and agency costs, also figure prominently in the neoclassical models. ${ }^{46}$ But the institionalists also mention nonrational phenomena, such as human attitudes. ${ }^{47}$ Authority and relational values also enter into the parties' transactional solutions: For example, fiat may be the cheapest way to solve problems; cooperation and reciprocity may reduce uncertainties, and hence costs, by causing expectations to converge. ${ }^{48}$

These differences result in a more thickly textured picture of the firm than that presented by the neoclassicists. Moreover, it embodies one main tenet of managerialism-the occurrence of a meaningful firm entity amidst an aggregate of individual transactions. With its hierarchies, planning failures, and bad faith conduct, the institutional variant approximates the picture of the firm underlying corporate legal doctrine.

Differences between the neoclassical and institutional pictures should not be emphasized too much, however. If we view both variants of the new economic theory together against the universe of alternative possible explanations of the firm, they represent a common point of view for many purposes. The institutional theorists, like the neoclassicists, view the firm as a contract and explain its structural features as

44. See Macneil, supra note 33, at 1043.

45. Benjamin Klein, Robert G. Crawford \& Armen A. Alchian, Vertical Integration, Appropriable Rents, and the Competitive Contracting Process, 21 J.L. \& Econ. 297, 298, 307-24 (1978), gives nice examples of firm-specific investments and transaction structures. For an analysis of corporate organization in terms of firm-specific investment, bounded rationality, and opportunistic conduct, see Oliver E. Williamson, Corporate Governance, 93 Yale L.J. 1197 (1984).

46. See Williamson, The Modern Corporation: Origins, Evolution, Attributes, supra note 42, at $1547-48$.

47. O. Williamson, supra note 26 , at 256-57.

48. Id. at $30-40$. 
the cost-saving devices of transacting parties. They share with the neoclassicists a noninterventionist political perspective. Since their firm "is contract," and since private actors do a better job at making contracts than do government officials, ${ }^{49}$ they see little constructive role for public policy. In addition, the institutionalists, like the neoclassicists, employ a methodology that delimits the scope of their inquiry and analysis. This approach assumes that transaction cost reduction best explains private contracting patterns, and they explain firm phenomena only as means to that end. When their inquiry does not lead to an explanation within this functional paradigm, both institutionalists and neoclassicists either try again or abandon the search; neither looks to the world of political, social, and economic behavior outside.

\section{The Historical Evolution of Legal Theories of the CoRPORATE FIRM}

This part recounts the evolution of theory of the firm concepts in American corporate law history. The account is divided into five stages: the early nineteenth century to 1850 ; the mid-nineteenth century to the 1880s; the turn of the century; the twentieth century to around 1980; and finally, the recent appearance of the new economic theory. For each of the first four stages the account sets out primary points from the economic history of corporations and from the history of corporate legal doctrine. It then relates these points to the period's theories of the firm. At the fifth stage, the account returns us to the contemporary end point introduced in part I-the conflict between managerialism and the new economic theory.

The story has a constant theme: The corporate entity rises, posing challenges to both economic and legal theory. Both types of theory are based on individualism. They employ models of economic life based on visions of production by individual producers and transactions between individuals, all of whom bear responsibility for their own actions. These models must be adjusted to account for group production. In the case of economic theory, with its construct of entrepreneurial, profit-maximizing behavior by rational economic actors, the adjustment requires that the individuals' entrepreneurial behavior patterns be reconstructed or replaced somewhere in the collective producing institution. An analogous adjustment takes place in the case of legal theory. The corporate unit must be integrated with a wider legal fabric that assumes individual actors, makes them responsible, and seeks to facilitate their development. ${ }^{50}$ As the corporation's economic significance increases, it becomes harder to reconcile its size and power with this

49. See Oliver Williamson, Organization Form, Residual Claimants and Corporate Control, 26 J.L. \& Econ. 351, 361 (1983).

50. For a recent statement of a general theory, see MeIr Dan-Cohen, Rights, Persons and Organizations: A Legal Theory for a Bureaucratic Society (1986). 


\section{individual-based system..$^{51}$}

The historical story climaxes when the management corporation appears at the turn of the century. Production by great collective entities becomes a reality rather suddenly. As collective production becomes more successful, theoretical adjustments consonant with individualism become harder to formulate. Successive efforts to resolve this tension mark the twentieth century history of the theory of the firm. The new economic theory is simply the latest exercise in the series.

\section{A. The Early Nineteenth Century to 1850}

Very little tension arose between economic practice and individualist economic and legal theory in the early nineteenth century. ${ }^{52}$ The economy closely resembled the atomistic type described in Adam Smith's classical theory. Economic units tended to be individual rather than collective. Individuals produced goods for sale in the market. Individuals bought goods for consumption in the market. To the extent production was organized, the market did the organizing by coordinating prices. ${ }^{53}$

Classical economic thinking integrated production and distribution with the wider scheme of politics and society. People assumed that market competition would keep the incompetence and greed of owners of the means of production under control. Thus, the competitive market legitimized private economic power. People also assumed that profit-oriented investors closely scrutinized the managers of firms. ${ }^{54}$ Thus, the figure of the rational profit maximizer legitimized the positions of decisionmakers in individual firms.

This individual perspective undergirded business law. Actors in the economic system received legal support from a regime of individual

51. Allen Kaufman \& L. S. Zacharias, The Problem of the Corporation and the Evolution of Social Values (1987) (Management Research Center Working Paper, Univ. of Mass. School of Management, Amherst, Mass.) (on file with the Stanford Law Review), casts the history of theories of the firm in the framework of nineteenth century ideological dualism, an approach currently popular among historians. "Civic republicanism," on the one hand, was egalitarian and stressed personal development. It viewed property as a prerequisite for developing the moral character of the citizen and for establishing the market as a meeting place for independent producers. Large corporations disrupted the civic republicans' economic assumption of widespread individual property ownership. "Liberalism," on the other hand, viewed property as an instrument for individual prosperity and property rights as a means of individual protection against the outside world. The corporation challenged the liberals' assumption of private, individual market competition. Id. at 5-8.

52. This was true at least once the Jeffersonian and Jacksonian adherents of classical, political economy eliminated Federalist mercantilist policies. See Herbert Hovenkamp, The Classical Corporation in American Legal Thought, 76 GEo. L.J. 1593, 1605-12 (1988).

53. See Peter Temin, The Jacksonian Economy 177 (1969) (the American economy in the 1830s "functioned to a large extent in the fashion described by what we now call classical economic theory"); Alfred D. Chandler, Jr., The Visible Hand: The Managerial RevoluTION IN AMERICAN BUSINESS 15-28 (1977).

54. See James Willard Hurst, The Legitimacy of the Business Corporation in the LAW OF THE UNITED States 1780-1970, at 82 (1970). 
possessory property rights. ${ }^{55}$ People did not yet associate the corporate form with general business, and, in fact, few businesses took the corporate form. This was corporate law history's "special charter" phase. Corporate doctrine, as received from Great Britain, held that the corporate form was instituted by the sovereign's grant of a charter. The American states tended to confer charters on businesses that received state franchises-e.g., public utilities, transport concerns, banks, insurers, and water works - and thus were perceived to require regulation outside of the market system. ${ }^{56}$

The prevailing legal theories described the corporation as a legal fiction and an artificial entity. ${ }^{57}$ Rephrased in modern terms, this meant that the corporation was an entity, and that the entity was a statecreated reification. This operative "concession" notion had been received from British law. With the special charter as the dominant mode of corporate creation, this concession-based corporate theory accurately described American corporate practice.

Contractualism also was part of the British inheritance. During the two centuries prior to the American Revolution, British lawyers had resisted the sovereign's assertions of authority to create new legal actors pursuant to concession doctrine. They maintained that only natural persons occupied the legal world, and they advanced contractual conceptions of the firm. ${ }^{58}$ American law, with its "artificial entity" and "Iegal fiction" concepts, carried on this tradition of individualism, 59 even as it conceded the existence of state-created juridical persons. The American concepts denied economic reality to the juridical construct. Corporations were "artificial" and "fictive" in part because observers looked to the conduct of individuals for the economic substance of businesses. ${ }^{60}$ Thus, American legal theory fastened the classical conception of the economy as a system of transactions among individuals onto a legal foundation of individual property rights.

This description must end on a complicating note, since, despite all

55. Adolf A. Berle, Jr., Coherency and the Social Sciences, in People, Power and Poumics 6, 10 (L.J. Gould \& E.W. Steele eds. 1961); $c$. A. BERLE, supra note 20, at 34-35 (property rights remained unchanged while corporations aggregated the power to plan the course of the economy).

56. J. HuRst, supra note 54, at 7-8.

57. See John Dewey, The Historic Background of Corporate Legal Personality, 35 Yale L.J. 655, 667-78 (1926); Paul Vinogradoff, Juridical Persons, 24 Colum. L. Rev. 594, 601 (1924).

58. Arthur J. Jacobson, The Private Use of Public Authority: Sovereignty and Associations in the Common Law, 29 Buffalo L. Rev. 599, 662-63 (1980).

59. Horwitz, supra note 14 , at 181 .

60. Chief Justice Marshall's opinion in the most famous corporate law case of the early period demonstrates this. The Dartmouth College case held that a "corporation is an artificial being, invisible, intangible, and existing only in contemplation of law." Trustees of Dartmouth College v. Woodward, 17 U.S. (4 Wheat.) 518, 636 (1819); see text accompanying notes 160-161 infra.

The charters themselves were viewed as contracts and not as equivalent to statutes. See Adolph A. Berle \& Gardiner C. Means, The Modern Corporation and Private Property 121 (rev. ed. 1968). 
the individualist concord, the legal foundations for later corporate collectivities were laid during this early period. Early American corporate practice was more extensive and more highly developed than any in contemporary Europe. ${ }^{61}$ According to Hurst, the legal form of the corporation had the functional capability for centralized production as early as the $1850 \mathrm{~s}$ - by then the doctrinal provisions of free transferability and unlimited life were in place. More important, the doctrine instantiated group values. Corporate law favored strong central direction of assets, barred stockholders from a direct managerial voice, and accorded management considerable assurances of tenure. ${ }^{62}$

\section{B. The Middle Period-the 1850 s to the 1880 s}

This was a transitional period in corporate history. Increased production by incorporated businesses ended the harmony between economic practice and individualist modes of thinking. Individualists began to object to corporate institutions, and devices designed to meet their objections showed up in corporate doctrine.

A factory economy developed during this period, as entrepreneurs launched the first manufacturing corporations. ${ }^{63}$ The corporation became a common legal form for doing business, including manufacturing and selling. ${ }^{64}$ The first great management hierarchies also appeared during this period, but these governed only the railroads. Manufacturing, while now corporate, continued under simple governance structures; substantial identity still existed between owners and managers. ${ }^{65}$

The states enacted "general corporation laws" to assure equal access to the corporate form. These laws emerged in a relatively set pattern, including provisions respecting corporate purposes, directors' powers, capital structure, dividends, amendments, and mergers. ${ }^{66}$

The proliferation of general corporation laws necessitated adjustments in the underlying theory of the firm. The "legal fiction" and

61. Oscar Handlin \& Mary F. Handlin, Origins of the American Business Corporation, in PuBlic Policy and the Modern Corporation 3, 7, 23-24 (D. Grunewald \& H. Bass eds. 1966).

62. J. HuRST, supra note 54, at 25 (stating that this "armed" management for "vigorous maneuver").

63. See Robert Charles Clark, The Four Stages of Capitalism: Reflections on Investment Management Trealises, 94 HaRv. L. REv. 561,562 (1981).

64. The corporate form ceased to be associated with "public interest" enterprises. The new corporations were industrial concerns, and the pace of industrial incorporation increased significantly after 1870. Peter George, The Emergence of Industrial America 79 (1982); see also A. CHANDLER, supra note 53, at 235-39, 240-47 (discussing the appearance of mass distribution systems and factory system, and the disappearance of the putting-out system).

65. A. Chandler, supra note 53 , at 237-38.

66. J. HuRst, supra note 54, at 37, 55-57, 69; see Gregory A. Mark, The Personification of the Business Corporation in American Law, 54 U. CHI. L. REv. 1441, 1455 (1987) (student author) ("The transformation of the private law of corporations from 1819 to the 1920 s is best described as a move from a circumstance in which a corporation could do only those things specifically allowed by its charter to one in which a corporation could do anything not specifically prohibited by it."). 
"artificial entity" notions were questioned because new statutes impaired their base in concession theory. With equal access to the form assured, corporations no longer seemed a product of sovereign grace. Although many still saw a reified corporate entity, widespread use of the corporate form directed attention away from juridical constructs and toward the social reality of the business and the creative energy of the individuals conducting it.

Widespread use of the corporate form also aroused individualist criticism. Individual economic power seemed to decline as corporate manufacturing expanded. With factory owners managing production, workers and consumers lost some of the control they had exercised through employment and purchase transactions in the earlier, atomistic economy. Other commentators charged that corporations subverted market control of private economic power. As separate economic entities, corporations diluted individual moral and legal responsibility among groups of business people. Furthermore, the corporate mode of conducting business through agents was criticized as inefficient, since the agents would never display the zeal of individual entrepreneurs. ${ }^{67}$

The management structures of the mid-century railroads presented the most striking departures from the classical economic model. Like later management corporations, these corporations had large managerial hierarchies and were financed by outside equity holders. But unlike later management corporations, which had large numbers of outside stockholders holding small blocks of stock, ${ }^{68}$ these railroads had small numbers of outside stockholders holding large blocks of stock. The railroads' outside equity investors sought an active role in their internal affairs. Outside investment bankers sat on the boards and exercised vetoes against management. Conflicts of interest arose because the financial interests wanted short-term profits while the managers took a long-term perspective. ${ }^{69}$

The classical economic model did not offer a solution for this conflict. It assumed that profit-maximizing, individual entrepreneurs both owned the means of production and directed production. With the railroads, this basic assumption no longer obtained: Groups of managers and investors, rather than individual actors, became the players. Furthermore, their interests came into conflict as ownership and direction of the means of production began to separate.

To address individualist concerns, corporate doctrine developed restraints against corporate and managerial power. To keep managers under control, the doctrine confined corporate activities within the parameters of a stated purpose. To keep corporations small, the doctrine

67. J. HuRst, supra note 54 , at 43,48 .

68. This pattern emerged after 1890 .

69. See A. Chandler, supra note 53, at 87, 120, 148; J. Hurst, supra note 54, at 82. 
limited their capital. ${ }^{70}$ Nevertheless, according to Hurst, descriptions of the middle period should not overemphasize this anti-corporate thinking and restrictive doctrine. Like the preceding and subsequent periods of corporate legal history, this one was kind to management. General corporation laws effectively defused egalitarian objections to the corporation. And corporate law legitimized broad authority to officers while it kept stockholders out of direct participation in the decisionmaking process. ${ }^{71}$

\section{From the 1880s through the Turn of the Century-The Appearance of the Management Corporation}

Management corporations appeared around $1890 .{ }^{72}$ Before then, small firms, whether individually owned or incorporated, had performed single tasks of production or marketing. Now they were joined, and in many cases replaced, by large corporations performing multiple tasks of production and marketing. ${ }^{73}$ The new corporations produced an array of goods cheaply and in quantity. People perceived them as a success. ${ }^{74}$

Hierarchies of salaried executives dominated these new corporations. Successful mass production required long-term policy commitments and substantial investment; professional, salaried managers were designated to make these formulations and to direct production. Actors on the capital markets withdrew from active participation in corporate management because they saw themselves as lacking in necessary expertise. The split in the classical entrepreneurial function, presaged

70. See J. Hurst, supra note 54 , at $45,55-57$; Robert S. Stevens, Handbook on the Law of Private Corporations 224-27, 331-36 (2d ed. 1949) (summarizing ultra vires doctrine); Horwitz, supra note 14 , at $186-88$.

71. J. HuRst, supra note 54 , at $37,45,55-57$. Corporate doctrine did facilitate some selfprotection by stockholders through proportional voting rules and proportional rights to subscribe to new issues of stock. On the other hand, mismanagement was not actionable without a showing of gross negligence. Id. at 49 . Although a corporate law of investor protection developed during this period, its beneficiaries were corporate creditors.

72. Means uses the term "collective capitalism." See Gardiner C. Means, The CorpoRATE REVOLUTION IN AMERICA 50-51 (1962). I use "management corporation" to avoid the particular political implications of Means's phrase.

73. A. Chandler, supra note 53 , at $14,285-86$.

74. Michael J. Piore \& Charles F. Sabel, The Second Industrial Divide 72 (1984).

Between 1899 and 1929 , the population rose $62 \%$, while industrial production rose $295 \%$ and power production rose $331 \%$. In 1929 , per capita production was $60 \%$ higher than in 1900. Robert Sobel, The Age of Giant Corporations 52-53 (2d ed. 1984).

The first great integrated enterprises appeared in the $1880 \mathrm{~s}$ and $1890 \mathrm{~s}$. Firms consolidated manufacturing into larger plants and expanded into operations other than production, including marketing, distribution, and raw materials procurement. See P. George, supra note 64 , at 82 . The result of their success was the decline of the older form of small, self-sufficient economic unit during the first decades of the twentieth century. R. SoBEL, supra, at 52-75.

The desire for monopoly profits was a principal motivation for integration and combination during the 1890 s, but other factors figured in. The formation of United States Steel, for example, also served the need for sources of raw materials-due to the increased size of plants-and the promoters' desire to reap profits in the financial markets. See PETER Temin, Iron and SteEl in Nineteenth-Century America 190-93 (1964). 
by the experience of the mid-century railroad companies, widened: Ownership of capital and control of the firm became completely separate. ${ }^{75}$

Management corporations rapidly came to dominate the economy. ${ }^{76}$ Their dominance occasioned a substantial relocation and reformulation of economic power. Corporate control of production partially displaced market control, causing power to flow from individuals to groups.

Recall that in the atomistic economy of the first part of the nineteenth century, the limited "control" or "coordination" that existed resulted from market forces. In such an economy, actors do not exercise power against one another unilaterally. Each individual decides for himself or herself what to produce or consume. Power relations are bilateral-one can affect another's conduct only indirectly, by refusing to contract. ${ }^{77}$ Since no one can direct production and consumption decisions, the economic system remains unplanned.

With management corporations dominant, entities, rather than transactions between individuals, guided the flow of goods through the processes of production and distribution. Some of this management power was effectively unilateral-hierarchical superiors directed subordinates in the production and marketing processes. As to other economic actors-investors, suppliers, and consumers-management groups exercised varying degrees of dominance in the context of bilaterally structured relations.

Different explanations have been advanced for the management corporation's displacement of the market-controlled economy. Assume that increases in productivity depend on increasingly specialized use of resources and that, in the nineteenth century, the division of labor and the development of special purpose machinery made greater productivity possible. ${ }^{78}$ Why did the management corporation become the institutional means to the end of greater productivity? Chandler offers an explanation from the perspective of cost economics. In his view, administrative coordination permitted greater productivity by lowering costs; corporations thus won out in the competitive marketplace. The internalization of units of production lowered transaction and information costs, and permitted more intensive use of resources. Internalization required management. ${ }^{79}$ Piore and Sabel offer a contrasting explanation centered on production. In their view, coordination of re-

75. This is the famous point of A. BERLE \& G. Means, supra note 60.

76. For the view that the management corporation need not dominate production in the future, see M. PIORE \& C. SABEL, supra note 74.

77. Macneil originated the term "bilateral power." It is the possibility of an exchange whereby two persons release one another from some of the restraints imposed by their respective unilateral powers. He defines unilateral power as any capacity a person has to subject another to some particular effect without the other's consent. Macneil, supra note 33, at 1036.

78. See M. PIORE \& C. SABEL, supra note 74, at 22-23.

79. A. Chandler, supra note 53, at 6-8. 
sources by the price system became impossible as industrial resources became highly specialized in the late nineteenth century. The new production technologies had high fixed costs, the recovery of which necessitated high levels of capacity utilization. To justify high utilization, markets had to be created. The price system could not, by itself, coordinate mass production and mass marketing, so the management corporation was devised to perform the task. ${ }^{80}$

During its "liberal incorporation" phase, lasting from around 1890 to 1930, corporate law facilitated the management corporation's successful appearance. New Jersey, and then Delaware, enacted new general incorporation acts in an effort to attract the charters of the large corporations. These new acts facilitated managerial action by offering standardized corporate structures without ancillary regulation of business decisions. Although nineteenth century forms of shareholder participation stayed in the statutes, shareholders did not invoke them to challenge management arrangements. Judge-made corporate law changed too. Mid-nineteenth century fiduciary strictures on managers disappeared rather suddenly. ${ }^{81}$ The fiduciary principle survived in name, but, in practice, the system tolerated individual selfishness.

The legal theory of the firm became a topic of debate just at the time management corporations appeared. Both sides of the debate rejected the earlier doctrinal notions of the corporation as "legal fiction" and "artificial entity." But they diverged in their responses to the management corporation. One side was individualist and hostile, hewing closely to classical economic notions. The other side abandoned individualism for "corporate realism," a metaphysical theory that proved congenial to management interests.

The hostile, individualist side advanced a contractual theory of the corporation. This theory incorporated the classical ideals of a disaggregated producer universe and control through market pricing. It carried on the individualism of the earlier "legal fiction" and "artificial entity" conceptions, even as it rejected concession theory, replacing the sovereign with freely contracting individuals. This theory took an aggregate, rather than an entity, approach ${ }^{82}$ - separate relationships comprised the corporation's ontological center rather than the force of the collective effort. Awkwardly, this contract theory was hostile to state regulation and to the management corporation simultaneously. Choosing a lesser evil, its adherents supported state-imposed restrictions on corporate activities through corporate law restrictions on size and purpose. ${ }^{83}$

80. M. ProRE \& C. SABEL, supra note 74, at 49-51.

81. See Robert Charles Clark, Corporate Law 160-66 (1986); Howard Marsh, Jr., Are Directors Trustees? Confict of Interest and Corporate Morality, 22 Bus. LAw. 35, 39-40 (1966) (strict rules dropped by 1910).

82. See I Charles Fisk Beach, The Law of Private Corporations 1-4 (1891); 1 Victor Morawetz, Private Corporations 1-2 (2d ed. I886); Henry O. Taylor, a Treatise on the Law of Private Corporations iv (1884).

83. See Horwitz, supra note 14 , at $183,204-05$. A suit based on the contractual concep- 
At the same time, however, lawyers representing management interests drew on contractualism to oppose regulation. For example, in 1886, contractualism served as the vehicle for protecting corporations from government regulation under the equal protection clause. ${ }^{84}$

The competing theory, corporate realism, drew on European ideas about the spiritual reality of group life, principally those of Otto Gierke. ${ }^{85}$ In the United States, its most prominent advocate was Ernst Freund, who advanced the theory in a book published in $1884 .{ }^{86}$ The theory achieved an anti-regulatory accent without individualism. The corporate entity was real, and group dynamics were more significant than individual contributions. With a real corporate entity, no meaningful split in the entrepreneurial function could occur; the management corporation reconstituted the classical profit maximizer in collective form. Thus, the theory resolved the tension between individualism and group production by privileging the group. But when attention turned to state regulation, individuals returned to the fore: Since individuals and not the state supplied the creative force that brought the group into existence, respect for individuals counseled against regulation. Corporate realism thus offered a theory of group production without state control. It suited the new management interest. ${ }^{87}$

The debate between contractualism and corporate realism lasted for only a brief period. Contractualism disappeared as a force in corporate legal theory after the turn of the century. People abandoned its underlying classical economic conceptions in response to the new corporations' success as producing entities, ${ }^{88}$ and the failure of the classical model adequately to describe complex, capital-intensive corporate entities and the oligopolistic economy in which they operated. After 1890, classical notions no longer influenced the formation of corporate law; the emphasis in that discourse shifted to legitimization of the producing group. ${ }^{89}$ In contrast, corporate realism survived in law reviews into

tion was brought against the Standard Oil Trust in State v. Standard Oil Co., 49 Ohio St. 137, 30 N.E. 279 (1892).

84. Santa Clara County v. Southern Pac. R.R., 118 U.S. 394 (1886). The court looked through the entity to the individual interests at stake and found something protectible. This is Professor Horwitz's thesis. He makes the case persuasively. See Horwitz, supra note 14, at 173 , 178; see also Mark, supra note 66, at 1463 .

85. Otto Gierke, Das Deutsche Genossenschaftsrecht (1887). Maitland advanced Gierke's ideas in the English-speaking world. See Otto Gierke, Polmical Theory of the MrdDle AGE i-xlv (F.W. Maitland trans. 1900) (introduction by Maitland). For a summary, see Frederick Hallis, Corporate Personality 137-65 (1930); see also Mark, supra note 66, at 1468-69.

86. Ernst Freund, The Legal Nature of Corporations (1884).

87. Horwitz, supra note 14 , at 176, 224; Mark, supra note 66 , at 1470.

88. Where, for a century, market competition and property law had legitimized power in individual hands, now management performance legitimized power in corporate organizations. J. HuRST, supra note 54 , at $59,62,70,82$.

89. See Mark, supra note 66 , at 1464-65. They survived as a restraining influence only in antitrust law. 
the $1920 \mathrm{~s}^{90}$-it offered a theory of groups.

In the mid 1920s, corporate realism also fell, the victim of a series of persuasive critiques, most prominently an essay by John Dewey. These critiques denied the existence of a real entity, putting forth a conclusive case for the reified corporation. ${ }^{91}$ After corporate realism disappeared, discussion of the nature of the firm in traditional legal terms nearly disappeared as well. ${ }^{22}$ Dewey asserted that the whole jurisprudence was pointless. The concepts, he said, were indeterminate. The same theories of the firm employed in advancing the case of management also advanced the case for labor, and they could be turned against the interests of either group. ${ }^{93}$

In a recent article, Professor Morton Horwitz reviews the turn-ofthe-century debates on the theory of the firm and deemphasizes Dewey's indeterminacy point. ${ }^{94}$ Horwitz acknowledges that Dewey correctly recounted the deployment of the same theory of the firm concept in support of different interests. But he contends nonetheless that corporate realism should be accorded some determinative significance in connection with the rise of the management corporation. Although theory of the firm concepts were manipulable, he says, corporate realism better legitimized the practices of the management corporation than any other theory then current. ${ }^{95}$ And he goes further: Corporate realism was a "major factor" in legitimizing the management corporation. ${ }^{96}$ This article returns to Horwitz's proposition in part IV. ${ }^{97}$

\section{The Twentieth Century to 1980}

Management corporations continued their rise during the first half

90. See George F. Deiser, The Juristic Person (pts. 1-3), 57 U. PA. L. Rev. 131, 216, 300 (1908-09) (realist); Harold J. Laski, The Personality of Associations, 29 Harv. L. Rev. 404 (1916) (realist); Arthur W. Machen, Jr., Corporate Personality (pts. 1-2), 24 Harv. L. Rev. 253, 347 (1911) (realist); George F. Canfield, The Scope and Limits of the Corporate Entity Theory, 17 Couum. L. REv. 128 (1917) (strong entity approach); Wesley Newcomb Hohfeld, The Individual Liabilit) of Stockholders and the Conflict of Laws, 10 Colum. L. REv. 283 (1910) (anti-realist); Wesley Newcomb Hohfeld, Nature of Stockholders' Individual Liability for Corporation Debts, 9 CouUM. L. REv. 285 (1909) (anti-realist).

91. Dewey, supra note 57; see also Morris Raphael Cohen, Reason and Nature 386-92 (Free Press ed. 1964); Max Radin, The Endless Problem of Corporate Personality, 32 Colum. L. REv. 643 (1932); Vinogradoff, supra note 57.

92. But see Sigmund Timberg, Corporate Fictions: Logical, Social and International Implications, 46 Colum. L. Rev. 533 (1946).

93. Dewey, supra note 57, at 669-70 ("Each theory has been used to serve the same ends, and each has been used to serve opposing ends. ... Unfortunately, the human mind tends toward fusion rather than discrimination, and the result is confusion.").

94. Horwitz, supra note 14.

95. Id. at 224 .

96. Id. at 176. "In the jargon of the current Critical Legal Studies debate," Horwitz denies the infinite "flippability" of legal concepts; he ascribes them "tilt" in determining outcomes. Id.

For a similar, but more cautiously stated view of the influence of corporate realism, see Mark, supra note 66, at 1478 .

97. See text accompanying notes 192-196 infra. 
of the twentieth century. The image of the corporation as an entity rose with them.

During this period, internal changes in corporate structure enhanced management discretion. Early management corporations had been single hierarchical units following a "line and organization" structure; that is, operations managers and top executives worked in the same unit. ${ }^{98}$ After the First World War, a new structure composed of multiple divisions appeared in a few leading corporations. The multidivisional corporation contained more than one operating unit and had a top management group responsible for all the units. Top management became separate from operations management. This permitted long-term policy to be formulated more effectively as decisionmakers were freed from localized biases stemming from ties to operating units. ${ }^{99}$ This form of organization became widespread after the Second World War, reaching maturity with the conglomerate corporations of the late $1960 \mathrm{s.}{ }^{100}$

Investment patterns also enhanced management discretion during this period. Shareholdings became widely dispersed as small investors joined the full-time capitalists as equity investors in management corporations. ${ }^{101}$ By the 1920 s and 1930s, management and these widespread equity investors reached an unspoken, working understanding about power and money. Managers of large firms "agreed" to maintain stable dividends in return for the freedom to pursue a "growth" strategy. A growth strategy would permit management to raise equity capital internally, thereby avoiding new issues of equity securities and accompanying market judgments about management performance. The capital markets, valuing corporate "growth," went along. ${ }^{102}$ The conventional wisdom, moreover, held that investors had to go along whether they liked it or not: There was a collective action problem. Under the "Wall Street Rule," individual stockholders never found it

98. The central office of United States Steel, a complex of many firms that merged over a short period in the late 1890 s, did little more than collect accounting information for the company's first decade. Central office expansion occurred after 1910. P. Temin, supra note 74 , at 192 .

99. A. Chandler, supra note 53 , at $462-63,482$. The new general executive had a beneficial psychological commitment to the enterprise as a whole. Id. at 463.

100. Williamson explains these developments with a cost efficiency model: Multidivisional structure facilitated strategic planning with a larger information set and better control and monitoring of operating units. The result was the direction of cash flows to higher yielding uses. The corporation thus internalized functions formerly performed by the capital market. Williamson, The Modern Corporation: Origins, Evolution, Attributes, supra note 42, at 1556. Once again we can turn to Piore and Sabel for a contrasting view focused on production operations rather than management costs. They see the direction of management energies to the building of portfolios of operating companies after World War II as a symptom of larger macroeconomic problems. Mass-producing corporations saturated their own markets without developing new products and new markets. Their risks increased as a result; diversification through conglomeration reduced the risk. M. PIORE \& C. SABEL, supra note 74, at 194-97.

101. Widespread public purchases of shares provided the heavy capitalization required by the new firms that appeared at the turn of the century. P. TEMIN, supra note 74, at 193 .

102. A. BERLE, supra note 20 , at 35,54 . 
cost effective to challenge the tenure of an ineffective management group; selling the shares was the best course of action. ${ }^{103}$ This unspoken understanding governed management/investor relations until the late 1970s.

Corporate law also continued to support management. The model of state corporate law originated by New Jersey and Delaware at the turn of the century became the national norm. In the 1930s, the federal government supplemented state law with the federal securities laws. These required public disclosure of material information for the benefit of investors and the securities markets. In contrast to state corporate law, the securities laws operated as a moderate constraint on management discretion.

Legal theories respecting the management corporation changed substantially around 1930. As already noted, Dewey's 1926 essay marked the end of the corporate realist discourse and of corporate theory articulated in traditional terms. ${ }^{104}$ An early and prominent exercise in law and economics, Berle and Means's The Modern Corporation and Private Property, ${ }^{105}$ marked the beginning of the new era. Berle and Means set out a paradigm based on managerialist concepts drawn from economics. In its day, corporate realism had surmounted the split in the entrepreneurial function by describing a transcendent corporate being akin to a profit-maximizing individual. With the abandonment of this notion, managerialism faced the problem of the corporation's inability to replicate exactly the individual economic actor's profit-maximizing behavior pattern. Managerialism highlighted tensions between the individual and the corporate collective, departing from the previous discourse in that individual interests came to be represented in socialized form by government and other "group" representatives. Berle and Means recognized that shares of stock no longer carried the traditional incidents of property ownership. They offered a substitute concept of shareholder/corporate relations built around intermediate securities markets. This was a contractual concept: Shareholders supplied capital and took risks, but then looked to the securities markets for fulfillment of their essential expectations of liquidity and appraisal. ${ }^{106}$ Failures in the operations of the marketplace required legislative intervention. ${ }^{107}$ But, even assuming successful technical correction of these failures, the shareholder interest could not be said contractually to control management. 108

Given this picture, which locates corporate power in the hands of

103. See J.A. Livingston, The American Stockholder 60-61, 66-67 (1958).

104. See text accompanying notes $91-93$ supra.

105. A. BERLE \& G. MEANS, supra note 60 .

106. See id. at 245-50. For a discussion of the implications of this contractual side of Berle and Means, see Kaufman \& Zacharias, supra note 51, at 20.

107. A. BERLE \& G. MEANS, supra note 60 , at $255-90$.

108. Berle and Means thus combined a contractual conception of the corporation with a Weberian bureaucratic conception: Corporations in part were management controlled bu- 
management, management legitimacy became an issue. Participants in the discussion chose to address the issue as one of policy-"social" policy-rather than one of legal theory or doctrine. ${ }^{109}$ This approach seemed to obviate the need for further philosophical discussion of the nature of the corporation.

Economists and legal academics shared the managerialist conception $^{110}$ of corporate structure and productive capability.

\section{Managerialist economics.}

Berle and Means's book popularized the basic points of institutional economics. Although these ideas already had been circulating in different forms for several decades, ${ }^{111}$ an even more extensive literature came after Berle and Means. Institutional economics analyzed the firm from outside of the assumptions and methodology of classical and neoclassical economics. It concluded that the classical model of efficient production, in which production occurs at prices tending toward producers' marginal costs, did not apply to corporate productive processes. Furthermore, market forces controlled neither the structure, the organization, nor the performance of management corporations. Within the management corporation, profit no longer was a motivating force. 112 With the separation of ownership and control, the entrepreneurial drive assumed in classical economics had become split between management and capital. Management, the group controlling the means of production, was not motivated primarily by profit-seeking, but by drives for power, prestige, and job security. ${ }^{113}$

The question was, absent behavior in the classical profit-maximizing mode, what behavior patterns and objectives characterized the management corporation? Institutionalists made many suggestions. The most famous replaced profit with "growth" as the objective,"14 and maximiz-

reaucratic entities vested with power by positive law, and in part were the contractual arrangements of economic actors. See M. DAN-Cohen, supra note 50, at 17-20.

109. Means, for example, promoted a new theory of the firm, a thickly textured analysis of the "corporate collective," bringing to bear actual economic, political, psychological, and anthropological observations. G. MEANs, supra note 72, at 63.

110. I use the term "managerialist conception" broadly to encompass entity conceptions of the management corporation in which management occupies a position of structural power. A narrower usage denotes a subcategory of theory in which managers function as neutral technocrats, balancing the conflicting interests of groups connected to the firm. See Masahiko Aoki, The Co-operative Game Theory of the Firm 34-37 (1984).

111. Thorstein Veblen was the most prominent predecessor. See Thorstein Veblen, Absentee Ownership (1923); Thorstein Veblen, The Theory of Business Enterprise (1904). For a review of the thinking about management prior to Berle and Means, see EDward S. Herman, Corporate Control, Corporate Power 5-9 (1981). 16.

112. A. Berle \& G. MEANs, supra note 60, at 299-308; see also G. MEANs, supra note 72, at

113. G. Means, supra note 72 , at 171 .

114. William J. Baumol, On the Theory of the Expansion of the Firm, 52 AM. Econ. REv. 1078 (1962). 
ing with "satisficing" as the behavior pattern. 115

While in some respects critical of management, institutionalist literature had a supportive aspect. It afforded a cost justification: The management corporation produced goods more cheaply than could disaggregated producers in a classical economic universe; management corporations produced and competed effectively, if not efficiently in the narrow sense. 116 The lack of direct controls on management, either by the price system or by the capital markets, did not necessarily present a serious problem. Growth was the mark of successful enterprise and successful managing. Managers sought it, and strong institutional pressures from investors and peers encouraged them to do so. ${ }^{117}$ This "growth bias" left managers close enough to classical profit maximizers. ${ }^{118}$

Economic theory also explained why the investment community viewed management's pursuit of the growth objective with equanimity. The theory of present value, advanced by Irving Fisher in 1930, aligned management's long-term investment perspectives with capital's often short-term investment perspectives. Since growth ultimately raised the level of dividend return, it manifested itself in present capital appreciation, that is, a higher stock price. ${ }^{119}$ Thus, long-term industrial stability and short-term profit came into balance, ${ }^{120}$ or so it seemed. ${ }^{121}$

Meanwhile, a separate discipline within economics-neoclassical economics-continued to operate in the classical tradition. Prior to the appearance of the new economic theory of the firm in the 1970s, however, neoclassical microeconomists declined to theorize about the internal operations of the management corporation, restricting their attention to the market. ${ }^{122}$ Their models explained coordination of the

115. Richard M. Cyert \& James G. March, A Behavioral Theory of the Firm (1963). For a short summary of this literature, see M. DAN-COHEN, supra note 50, at 20.

116. See generally William J. Baumol, Business Behavior, Value and Growth (1959); Robin Marris, The Economic Theory of 'Managerial' CaptTalism (1964); Buxbaum, supra note 22 , at 522-24.

117. See A. Chandler, supra note 53, at 484-500; Edward S. Herman, The Limits of the Market as a Discipline in Corporate Governance, 9 DEL. J. CoRP. L. 530, 533-34 (1984). Chandler finds a close relationship between the push for growth and the development of the multidivisional firm. The desire for firm security from disruption of supplies or outlets results in growth through vertical integration. Multidivisional growth also is productive: The conglomerate firm adding a unit of production causes better use of the new unit. A. ChandLer, supra note 53 , at 486 .

118. This is Herman's thesis. E. Herman, supra note 111, at 106-13; Herman, supra note 117 , at 533 .

119. Irving Fisher, The Theory of Interest (1930); see also A. Berle \& G. Means, supra note 60, at 247-48. On dividend policy, see John Lintner, Distributions of Incomes of Corporations Among Dividends, Retained Eamings and Taxes, 46 AM. ECON. REv. 97 (May 1956) (papers \& proceedings); see also Richard A. Brealy \& Stewart C. Myers, Principles of Corporate Finance 10-15 (2d ed. 1984).

120. See A. Chandler, supra note 53, at 10, 473-74, 492; J. HuRst, supra note 54, at 82.

121. For an account of the disruption of this balance in the 1980 s, see text accompanying notes $215-221$ infra.

122. The neoclassical models' assumptions of costlessly created and enforced contracts and perfect information obviated the need to inquire into organizational structure. See Jen- 
use of resources and distribution of income by the price system. ${ }^{123}$ They employed the received model of the single-product firm operating in a static but highly competitive environment. This firm was owned by a single proprietor who strived to maximize profits, using only output and price as strategic variables. ${ }^{124}$ This approach reduced the firm to a "black box"- a "production function" deemed to follow profit considerations exclusively and behave as an entity in rational patterns no different from those of human actors. Managerial power, if it existed at all, was assumed to be effectively controlled by market forces. ${ }^{125}$

In the age of the management corporation, this limited inquiry made neoclassical microeconomics a discipline of obviously limited explanatory capabilities. ${ }^{126}$ Yet microeconomists did not perceive a debilitating problem and rush to expand their models. They thought of actions inside firms as "engineering"-functions of hierarchical structures-and therefore not a subject matter suited to a discipline that studies markets. ${ }^{127}$ The neoclassicists' hierarchical conception of internal firm affairs signified concurrence in the managerialist conception prevalent among the institutionalists and academic lawyers. ${ }^{128}$

sen, supra note 8, at 325-26; see also Nathan Rosenberg, Comments on Robert Hessen, "The Modern Corporation and Private Property: A Reappraisal," 26 J.L. \& Econ. 291, 295 (1983). (1983).

123. See Steven N.S. Cheung, The Contractual Nature of the Firm, 26 J.L. \& EcoN. 1, 18

Following Adam Smith's dictum that the division of labor, and thus the firm, establishes the boundaries of the market for analytical purposes, see A. CHANDLER, supra note 53, at 48990 , neoclassical economists did not look at production processes inside the firm or at the contracting arrangements underlying them. See Harold Demsetz, The Struclure of Ownership and the Theory of the Firm, 26 J.L. \& Econ. 375, 377-78 (1983).

124. Mark Blaug, The Methodology of Economics 175-86 (1980).

125. See Milton Friedman, Capitalism and Freedom 121, 135 (1962); see also Jensen \& Meckling, supra note 4, at 306; Williamson, supra note 45, at 1220-21. Neoclassical models avoided taking entrepreneurship and its concomitant, profit, into account through singleminded adherence to the concept of marginal productivity. In perfect conditions, entrepreneurs theoretically have no function and receive no income. Profits thus were conceived in terms of imperfect competition and disequilibrium conditions, and explained either as payment for the assumption of uninsurable risks or as temporary windfalls. See Paul J. McNulty, On the Nature and Theory of Economic Organization: The Role of the Firm Reconsidered, 16 HIST. PoL. ECoN. 240-41 (1984).

Neoclassical theory valued production by small traditional enterprises subject to the invisible hand. Production by internal administrative coordination is suboptimal because of the absence of perfect competition. These values prove unexpectedly complementary to those reflected in the anti-managerialist discourse in the legal academy. Both accept the hierarchical nature of the corporation and both question the legitimacy of management power, albeit from different points of view.

126. For criticism of the neoclassical model, see M. BLAUG, supra note 124, at 176-78; A. Chandler, supra note 53, at 489-91; Ronald CoASE, The Firm, THE Market and THE Law 5-6 (1988); Harold Demsetz, Theory of the Firm Revisited, 4 J.L. ECON. \& ORG. 141, 142-44 (1988); McNulty, supra note 125; Nordquist, The Breakup of the Maximization Principle, in REAdings in Microeconomics 278 (D. Kamerschen ed. 1965); Sidney G. Winter, On Coase, Competence, and the Corporation, 4 J.L. Econ. \& ORG. 163, 165-71 (1988).

127. See Meckling, supra note 31 , at 557. and law.

128. The widely differing perspectives clashed mostly over questions of antitrust policy 


\section{Managerialist law.}

Berle and Means also contributed a political picture of the management corporation which prevailed in academic legal discussions until the new economic theory of the firm appeared to challenge it around 1980. As already stated in part $I,{ }^{129}$ this political picture identified management as a powerful group. This power stemmed from corporate structure: The traditional legal model of corporate ownership had combined with passive, widespread securityholding to leave management in a strategic position. The result was real power at the top of a dependent structure, ${ }^{130}$ and the issue was management legitimacy.

The debate over management legitimacy included one issue stated in terms of traditional legal theory. This issue-whether the corporation was public or private-addressed the validity of government regulation. A century earlier, concession theory would have justified regulation. But concession had fallen out of currency; its imagery no longer made sense. ${ }^{131}$ Accordingly, advocates of regulation reformulated the political assertions bound up in concession theory. They abandoned the sovereign creation story and accepted the primacy of individual creativity and energy in corporate life. But they characterized the product of all this individual activity as "public" in nature. This characterization supported the position that uncontrolled management wielded its power illegitimately and should be subjected to additional legal controls. The contrary "private" characterization affirmed the legitimacy of vesting in management substantial discretion.

Anti-managerialists demonstrated the firm's public nature by analogizing managerial power to governmental power. Like government, large corporations took actions important to those outside of the organization. Like government authorities, managers exercised their power by means of a rationalized system of control and administration. Like the government, the "public" firm was a "political" entity. ${ }^{132}$ Political theories respecting government, such as interest group pluralism, therefore should be applied to it. ${ }^{133}$

129. See text accompanying notes 18-21 supra.

130. A. BerLe \& G. MeANS, supra note 60, at 244-52, 309-13; see also Herman, supra note 117 , at $530-33$.

131. Bratton, supra note 17 , at

132. See Earl Latham, The Body Politic of the Corporation, in The CoRporation IN MODERN SocieTY 218 (E. Mason ed. 1966); R. NADER, M. GREen \& J. SELIGMAN, supra note 20, at 33, 36-37. Anti-managerialist commentary written instead in the post-Realist proceduralist tradition declines to make the "public" and "political" assertion. See Melvin Aron Eisenderg, THE StRUCTURE OF THE CoRporation 16 (1976) (corporate law is "constitutional"-that is, it "regulates the manner in which the corporate institution is constituted").

133. The analytical framework of interest group pluralism prevalent during the post-war period was so applied. Cf. Morton Horwitz, The History of the Public/Private Distinction, $130 \mathrm{U}$. PA. L. REv. 1423, 1427 (1982) (describing changing views of the public interest).

The anti-managerialists underpinned their "public" and "political" assertions with a historical story. Generations of law students have been introduced to the subject of corporations through this story as retold in the first chapter of WILliam L. CARY \& MELvin ARON EisEN- 
The "public" theme also figured into doctrinal fairness jurisprudence. Corporate doctrine follows the trust model in name only. In practice, it leaves substantial room for self-interested conduct by corporate managers. Anti-managerialists drew on the analogy to government in their criticism of the doctrine's managerialist bias. Our system normally treats public offices as trusts. We require public officers to show respect for others, even-handedness, and selflessness in situations in which we leave private persons unregulated. ${ }^{134}$ Given these assumptions, a "public" model of corporations implies strict scrutiny of the managerial actions affecting the interests of investors. ${ }^{135}$

\section{E. The Contemporary Debate-The New Economic Theory Versus Managerialism}

With the new economic theory, neoclassical microeconomists surmounted the conceptual barriers that prevented them from elaborating a modern theory of corporate structure. ${ }^{136}$ The solution was simple. The new theory avoided direct consideration of hierarchies in management corporations, setting out a picture in which corporate entity and hierarchy were irrelevant. By describing all internal relationships as market transactions, the theory permitted large organizations to be discussed within the traditions of neoclassical microeconomics. No acknowledgment of "engineering" sullied the theorists' hands.

berg, Cases and Materials on Corporations 1-15 (5th ed. 1980); see also R. Nader, M. GREEN \& J. SEligman, supra note 20, at 36-37,62-65 (a nice telling of the story). In the early 19 th century, corporate formation was a matter of special chartering by state legislatures. In those days, legal doctrine treated corporate power as a concession of sovereignty. Then, during the course of the nineteenth century, special chartering waned and then disappeared. Insofar as it promoted equal access to the corporate form, this was a salutary development. Unfortunately, dark forces took control around the turn of the century. States ceded legal control to management groups in exchange for tax dollars. These bad faith transactions permitted corporations to escape their historical duty to serve public ends, even as corporations continued to derive their constituent and legitimizing power from the state and to share its sovereignty. See Latham, supra note 132, at 223; see generally Jacobson, supra note 58.

134. See Christopher Stone, Corporate Vices and Corporate Virtues: Do Public/Private Distinctions Matter?, 130 U. PA. L. REv. 1441, 1449, 1480 (1982).

135. This movement gathered force in the 1960s, eclipsing the managerialist expertisebased approach. In the $1970 \mathrm{~s}$, anti-managerialists dominated the law reviews. Despite this, state corporate law remained substantially pro-managerial into the 1980 s.

The literature on transfers of control provides a good example of this phenomenon. Academics argued strongly against the legitimacy of managers exchanging control power for money. See, e.g., William D. Andrews, The Stockholder's Right to Equal Opportunity in the Sale of Shares, 78 Harv. L. Rev. 505 (1965); Adolf A. Berle, Jr., "Control" in Corporate Law, 58 Colum. L. Rev. 1212 (1958). A few cases took up the idea. See Rosenfeld v. Black, 445 F.2d 1337 (2d Cir. 1971); Perlman v. Feldmann, 219 F.2d 173 (2d Cir. 1955). But academic criticism was never fully incorporated into doctrine; most judges saw nothing wrong with the practice. See Clagett v. Hutchison, 583 F.2d 1259 (4th Cir. 1978); Essex Universal v. Yates, 305 F.2d 572 (2d Cir. 1962); Honigman v. Green Giant Co., 208 F. Supp. 754 (D. Minn. 1961), aff'd, 309 F.2d 667 (8th Cir. 1962), cert. denied, 372 U.S. 941 (1963); Easterbrook \& Fischel, Corporate Control Transactions, supra note 22 , at 716.

Despite this general trend, a few anti-managerial innovations have come into corporate doctrine during the present decade. See note 235 infra.

136. See text accompanying notes 122-128 supra. 
The neoclassical new economic theory pronounced a new solution to the problem of the split entrepreneurial function. Where turn-ofthe-century corporate realism patched over the split with a unified, real corporate being, the new economic theory offered the converse solution of a completely deconstructed corporate entity. Since no cognizable corporate collectivity appears amidst the nexus of contracts, no tension arises between collective and individual interests. The new theory does not look for corporate replication of individual profit-maximizing. The entrepreneurial function emerges in separate but unified pieces among the aggregated individuals. Ironically, this solution draws on the same classical tradition that originally stated the problem.

With this market-based solution, the neoclassicists rebutted both the managerialists' statement of the corporate problem and their regulatory solutions. The neoclassical picture privileges the firm's aggregate parts almost absolutely, deconstructing the hierarchy that the antimanagerialists attack. The managerialist corporate entity almost disappears, dissolving into disaggregated but interworking transactions among the participating actors. All of these interworking firm transactions resemble one another. ${ }^{137}$ The "separation of ownership and control," on which the managerialist picture based management power, no longer matters. "Ownership" becomes as irrelevant a concept as "firm entity." The "firm" is only a series of contracts covering inputs being joined so as to become output. "Capital," and thus the traditional legal situs of ownership, devolves into one of the many types of inputs. ${ }^{138}$

Though the neoclassicists nominally made these moves for the purpose of explanation, their operative assumptions gave the theory a normative aspect. Treating hierarchy as if it does not exist offers wonderful support to those at the top of the hierarchy, so long as the treatment implies no concomitant reordering of the status quo. Moreover, by challenging the anti-managerialist critique of corporate law, ${ }^{139}$ the neoclassicists in some respects challenge the status quo in management's favor. They rebut the anti-managerialists' "public" characterization with a model of "private" contracts among successfully contracting market actors. "Concessions" of sovereign authority have no place in this picture of free contract.

By stripping the content from the firm entity and introducing the self-interested rational economic actor, the new theory also rebuts the concept of fiduciary duty. Legal duties of selflessness do not figure into

137. Some transactions have the firm entity as a party, but only as a matter of convenience. The "firm" in the picture has no precise boundaries-unlike legal academics, the neoclassicists have no interest in categorizing transactions as occurring "inside" or "outside" of the firm. See Jensen \& Meckling, supra note 4, at 311; Klein, supra note 38, at 373; Klein, Crawford \& Alchian, supra note 45, at 326.

138. See Alchian \& Demsetz, supra note 25 , at $781-83,789$ n.14 (owners contract for rights to anticipated residual awards).

139. See generally sources cited in note 22 supra; Winter, supra note 9; Nicholas Wolfson, $A$ Cnlique of Corporate Law, 34 U. Mrami L. Rev. 959 (1980). 
the neoclassicists' conception of bilateral contract relations. ${ }^{140}$ These market contracts implicitly justify what they depict: Since they are priced to take management self-interest into account, extant customs of managerial self-dealing therefore must be all right, or cost competition would have caused them to disappear long ago. None of this was lost on participants in the corporate governance debates of the late $1970 \mathrm{~s}$ and early 1980s. To one anti-managerialist observer, the new economic theory completes the twentieth century trend toward loosened fiduciary restraints and enhanced management discretion. ${ }^{141}$ In fact, management spokespersons did make dramatic use of the theory in the early 1980 s $^{\mathbf{1 4 2}}$ to protest the first draft of the American Law Institute's Principles of Corporate Governance. ${ }^{143}$

The institutionalists, with their roots in managerialism, developed a variant of contractualism which does not offer an absolute solution to the split in the entrepreneurial function. The opportunistic conduct and bounded rationality of their actors leave room for tensions between individuals and corporate collectives that do not self-resolve. Nonetheless, like the neoclassicists, their work offers normative comfort to management interests. They legitimize the received hierarchical picture of the management corporation ${ }^{144}$ as a contractual arrangement which minimizes transaction costs. Their picture also makes the corporation a "private" phenomenon. They affirm the corporate structure and management's place in it, even as they admit the possibility of contract failure.

Some of the new economic theory's initial success in the legal academy may be attributable to this support of management. The new economic theory brought academic theory into line with the practices of corporate doctrine. The academic line had stressed managerial public duty and legal constraint. Corporate doctrine equivocated; it repeated the fiduciary principle and maintained a governmental presence even as it steadfastly protected the management corporation's private law bases and the discretionary authority of managers. Management power had supporters in academia as well as opponents. Supporters saw a voluntary side to individual relations with corporations, and the new eco-

140. See Bratton, supra note 17 , at - .

141. Brudney, supra note 22 , at 1410 .

142. See Statement of the Business Roundtable on the American Law Institute's Proposed "Principles of Corporate Governance and Structure: Restatement and Recommendations" 3-5 (1983); Paul W. MacAvoy, Scott Cantor, Jim Dana \& Sara Peck, ALI Proposals for Increased Control of the Corporation by' the Board of Directors: An Economic Analysis, in id. at C-1 (Exhibit C).

143. Principles of Corporate Governance and Structure: Restatement and RecomMENDATIONS (Tent. Draft No. 1, 1982). The ALI's draft was based on prevalent anti-managerialist assumptions.

144. Indeed, the institutionalist picture is derived from the historical work of Alfred Chandler. See generally Williamson, The Modern Corporation: Origins, Evolution, Attributes, supra note 42. 
nomic theory articulated this perception. ${ }^{145}$

\section{F. Summary}

In the classical world of the early nineteenth century, economic practice and theory coexisted in peace. Corporate production was an anomalous feature of the economic landscape. The corporation was integrated into the classical picture by a limiting theory-it was a legal institution only. But as the century proceeded and corporate production became the norm, it became clear that the corporate firm was more than a legal institution. The entrepreneurial function became split in economic practice, and the classical peace ended. Legal theory offered two opposing solutions. One, contractualism, sought to minimize the split and protect the individual by suppressing the corporation. The other, realism, made the split irrelevant by transcending the individual interest with a spiritual firm entity. Neither solution wore well in the twentieth century.

In the twentieth century, the management corporation became a normal institution. But the classical reproach continued to influence theoretical perspectives. With managerialism, the split entrepreneurial function became the base point of both economic and legal theory. Nineteenth century individualism, however, did not dominate managerialist responses to the classically-stated problem. In the ongoing discourse of legitimization, individual, bilateral relations within corporate entities were obscured amidst the concepts and habits of social policymaking. In legal theory, the individualist impulse remained largely subordinated until the appearance of the new economic theory. With this new theory, twentieth century individualists integrated classical theory and twentieth century practice. This theory offered a return to a world of classical peace: It healed the split entrepreneurial function and returned the corporate entity to limited life as a legal institution.

\section{The Nonevolutionary History of the Doctrinal Theory of THE CORPORATE FiRM}

A second, nonevolutionary history of the theory of the corporate firm parallels the foregoing evolutionary account. It deals with the same juridical concepts, but it shows that, when deployed to support corporate doctrine, these concepts have remained substantially constant in history. This account looks only to corporate doctrine, drawing on the definitions of the firm operative in treatises and other doctrinal work from the mid-nineteenth to the mid-twentieth century. These sources state a "doctrinal theory of the corporate firm" that was formu-

145. This recognition of a historical contribution should not be taken as an assertion that the new economic theory accurately modeled corporate legal practice. If we were to take the neoclassical variant as system and follow it as an absolute guide, we soon would be reconstructing rather than recreating the practice. 
lated during the early period and lasted into the twentieth century. The theory survived the late nineteenth and early twentieth century discussions of realism and contractualism-they proceeded around it, but did not cause its alteration. It again survived when juridical theory of the firm discourse lost credibility around 1930-the mid-twentieth century writers changed the vocabulary, but restated the historical concepts. It continues to inform corporate doctrine today.

This account shows that as the focus of attention shifts from theory to practice, historical tensions between individualism and the demands of collective enterprise ease. The doctrine mediates the tensions. It amalgamates the theoretical alternatives, averting controversy by balancing the variant points of view advanced in more purely theoretical contexts. Thus, the doctrinal theory of the firm is capacious. And it appears to have performed a useful function: As a base of agreement on basic conceptions, it has permitted corporate law decisionmakers to subordinate theoretical concerns and look to the particulars of situations in deciding cases. ${ }^{146}$ To the extent the doctrinal theory embodies values, they are those of the traditional corporate practitioner, rather than those of the legal or economic theorist, or those of the corporate chief executive officer or the Wall Street investment banker. To the practitioner, corporate law facilitates the activities of others in a regulated context. To achieve this, the law integrates concepts that in isolation would be in tension with one another.

\section{A. The Angell and Ames Definition}

The doctrinal theory of the firm may be traced, in America, to Angell and Ames, ${ }^{147}$ the leading antebellum corporate law treatise. ${ }^{148}$ Angell and Ames dealt with the problem of devising a theoretical characterization of the corporation by drawing on definitions from three prominent works. ${ }^{149}$ One definition came from Kent's Commentaries, ${ }^{150}$ but had origins going as far back as the writings of Pope Innocent

146. Both the historical definitions of the firm and the post-1930 reconstructions describe business organizations and their legal structure. All of the treatise writers employ an essentialist methodology in defining the corporation. The observer looks at events and proceeds by inductive enumeration until the universal in the events, their essence, has been grasped. The essence becomes the definition of the phenomenon. See M. BLAUG, supra note 124 , at 125 . Since by the turn of the century the corporation included everything from the corner grocery store to the largest management corporation, the historical definition took on considerable breadth. While capturing a broad essence, the writers explicitly defer most normative considerations to other contexts. This pragmatic move away from theoretical dominance illustrates corporate doctrine in its facilitative mode. Both the doctrine and the theory underlying it provide legal structures to accomplish ends formulated by policymakers.

147. Joseph angell \& Samuel ames, Treatise on the Law of Private Corporations Aggregate (9th ed. 1871).

148. See Horwitz, supra note 14, at 215.

149. J. ANGELL \& S. AMES, supra note 147 , at 1.

150. 2 James Kent, Commentaries on American Law 303 (11th ed. 1866). Kent's definition had been incorporated into the Louisiana Civil Code from 1825 through 1987. LA. Crv. Code ANn., art. 427 (West 1952 \& Supp. 1989) (repealed in 1987). 
IV. 151 The second came from Kyd's late eighteenth century British treatise on corporate law. ${ }^{152}$ The third was the famous description of the corporation in Chief Justice Marshall's opinion in the Dartmouth College case. ${ }^{153}$ This section closely examines each of these three texts.

First, the definition Angell and Ames drew from Chancellor Kent:

A corporation is [an artificial and fictitious] ${ }^{154}$ body, created by law, composed of individuals united under a common name, the members of which succeed each other, so that the body continues the same, notwithstanding the change of individuals who compose it, and is, for certain purposes, considered as a natural person. ${ }^{155}$

This definition begins with an anti-realist conception of the nature of the corporation: Artificial bodies ${ }^{156}$ are reifications. The phrase "created by law" brings in the notion that the corporate reification originates as a concession from the state; implicitly, the creating law is positive law. But the definition balances this implication with an antipositivist conception of firm life: While the state creates the reification, the corporation is "composed of individuals." Here the definition also makes an oblique reference to the firm's aggregate aspect. The reference does not go so far as to ascribe "contractual" origins to the corporation in a legal sense, but in an economic sense it can be taken to locate the source of creative energy in individuals, rather than in the state. The definition's image of the corporate body remaining the same while individual members succeed each other ascribes content to the firm reification; something separate from the individuals exists.

The definition's final, uncontroversial point-that the corporation is considered a natural person for certain purposes-is noteworthy for its careful anti-realism. The corporation is a person for doctrinal purposes only, being classified with individuals in some doctrinal contexts even though it is not a natural person. The Supreme Court has followed this situational practice in dealing with questions of corporate constitutional rights for more than a century. ${ }^{157}$

151. Timberg, supra note 92 , at 540. According to Conard, it may not have been Pope Innocent IV but rather one of his editors who recognized in an introduction that corporations are both material and immaterial, that they have individual members, but that corporations as a whole are not natural but intellectual. See Alfred Conard, Corporations in Perspective 417 \& n.5 (1976) (quoting Baldus Ubaldi, in "Index" to Innocentius, Commentaria, sub. tit. Universitas, the text credited with the origination of fiction theory).

152. 1 Stewart Kyd, A Treatise on the Law of Corporations 13 (1793).

153. Trustees of Dartmouth College v. Woodward, 17 U.S. (4 Wheat.) 518, 636 (1819).

154. 2 J. KENT, supra note 150 , at 303-04.

155. J. ANGell \& S. AMES, supra note 147 , at 1 (footnote added).

156. Id. at 4. Angell and Ames use this and other terms to capture Kent's point.

157. See First Nat'l Bank v. Bellotti, 435 U.S. 765 (1978) (corporations accorded first amendment rights); Hale v. Henkel, 201 U.S. 43, 68-83 (1906) (corporations accorded fourth amendment rights but not fifth amendment self-incrimination privilege); Minneapolis \& St. L. Ry. v. Beckwith, 129 U.S. 26, 28 (1889) (corporations accorded fourteenth amendment due process rights); Santa Clara Co. v. Southern Pac. R.R., 118 U.S. 394 (1886) (corporations accorded equal protection rights); Bank of Augusta v. Earle, 38 U.S. (13 Pet.) 519, 587-92 (1839) (corporations not citizens within privileges and immunities clause of art. IV). 
Second, the Kyd definition:

A corporation, or a body politic, or body incorporate, is a collection of many individuals, united into one body, under a special denomination, having perpetual succession under an artificial form, and vested, by the policy of law, with the capacity of acting, in several respects, as an individual, particularly of taking and granting property, of contracting obligations, of suing and being sued, of enjoying privileges and immunities in common, and of exercising a variety of political rights, more or less extensive, according to the design of its institution, or the powers conferred upon it, either at the time of its creation, or at any subsequent period of its existence. ${ }^{158}$

Kyd leans to the corporation's aggregate aspect more than does Kent. We get the same image of united individuals, but Kyd fixes on the idea of a "denomination" to describe the firm. He thus limits the firm entity's substance to the common name of the collection of individuals. ${ }^{159}$ Kyd acknowledges positive law aspects of firm creation, but he deemphasizes concession theory. His definition includes the point about contextual treatment of the corporation as if it were an individual. He then restates the point more broadly, leaving out any assertion that the state creates the firm reification. In sum, Kyd minimizes the significance of both the corporate entity and state participation in corporate life. His corporation is a legal device that facilitates common action. The substance lies with individual contributions.

Finally, Chief Justice Marshall's discussion:

A corporation is an artificial being, invisible, intangible, and existing only in contemplation of law. Being the mere creature of law, it possesses only those properties which the charter of its creation confers upon it, either expressly, or as incidental to its very existence. These are such as are supposed best calculated to effect the object for which it was created. Among the most important are immortality, and, if the expression may be allowed, individuality. ... Its immortality no more confers on it political power, or a political character, than immortality would confer such power or character on a natural person. It is no more a state instrument, than a natural person exercising the same powers would be. ${ }^{160}$

Chief Justice Marshall's first sentence, the foundation citation for early nineteenth century "fiction theory," depicts the corporation as a reification and presents a concession theory of its origin. The second and third sentences, noting the corporation's limited powers, set out the conception undergirding ultra vires doctrine. But the operative conception may be characterized more broadly. These sentences offer a functionalist conception of the corporation: Its powers have purposes; they

158. $1 \mathrm{~S}$. KYD, supra note 152 , at 13.

159. The new economic theories of the firm make a similar move when they strip the entity down to a contracting nexus. See text accompanying notes 28-40 supra.

160. Trustees of Dartmouth College v. Woodward, 17 U.S. (4 Wheat.) 518, 636 (1819). 
are means to ends. This functionalism follows from Chief Justice Marshall's anti-realist conception: Since the corporation is not a natural person it has no ability to formulate its own purposes and follow them. Less than a person, it is only a means to prescribed ends.

Chief Justice Marshall's comments on corporate immortality and "political power" were directed to the application of the contract clause of the constitution to the Dartmouth College charter, the issue disputed in the case. He moves toward a contractual ruling by utilizing the public/private distinction and finding the corporation, in substance, to be private-the corporation's legal foundations should not lead it to be treated in law as a government department it does not otherwise resemble. ${ }^{161}$ Here Chief Justice Marshall recognizes that the corporation includes voluntary private relations, and balances a concession conception with contractualism.

Significant commonalities tie the three definitions together, despite their variant vocabularies and emphases. Each definition conceives of the corporation as a reification, finding reality in the actions of individual participants. Each simultaneously recognizes entity and aggregate characteristics, concession and contractual origins, and public and private aspects. Which aspect proves relevant in a given situation depends on the facts and the particular observer's perspective. Kent and Chief Justice Marshall may be distinguished from Kyd for stronger emphasis on the entity. Kyd permits virtually nothing in the way of determinate thought structures inside his corporate entity, and Kyd's lesser emphasis on concession follows from his treatment of the entity: The less content in the entity, the less practical significance attaches to the state's act of creating it.

Professor Conard wrote a decade ago that the theory of the firm tends to be relevant to the placement of corporations in a legal order whose sentences speak in terms of human beings. ${ }^{162}$ If we take Angell and Ames's collection of definitions as a theory of the firm, then we should have low expectations of its ability to fulfill this ordering function. The definitions almost determinedly lack concepts that promise to determine results in concrete situations. In effect, they tell us that doctrinal principles and policies stem from particular juridical contexts rather than from the corporation's intrinsic nature.

In the same passage, Conard scrutinized the definitions from Angell and Ames, attacking their fiction and invisibility notions. Modern firms, he said, have a real presence, as individuals and labor united for economic purposes. We should, he said, follow Europeans to find a social reality beyond the juridical reality, looking to the social facts of group coherence and discipline. ${ }^{163}$ Conard refought an old battle here, but it

161. See Mark, supra note 66 , at $1448-50$.

162. A. Conard, supra note 151 , at 441 .

163. Id. at 442 . 
is worth pointing out that these historical definitions, carefully read, contain nothing to interfere with the search for corporate social reality. Kent, Kyd, and Chief Justice Marshall each recognize the corporation as a confluence of social reality and juridical construct, and balance both components as they attempt to capture its essence. Had the field of vision of any of the three included the elaborate hierarchy of the management corporation, his definition could have accommodated it without any fundamental reconstruction of operative concepts.

\section{B. Usage of the Angell and Ames Definition Prior to 1930}

The Angell and Ames definition, or in some cases one or two of its three components, became standard matter. The succeeding century's corporate law treatises repeated it again and again. ${ }^{164}$ The definition even can be found, stated as living legal doctrine, in a treatise published in 1958. ${ }^{165}$

Taking this usage as evidence of an enduring doctrinal conception of the corporation raises questions. One can imagine generations of treatise writers repeating an old text again and again without evaluating its plausibility anew. Doubtless some repetition of that sort has occurred here. Absent indications that the writers thought carefully about the theory of the firm when repeating the Angell and Ames definition, one would be justified in finding its persistence without significance. But these texts offer a great deal of evidence of reflection and considered affirmance of the definition's construct. The definition therefore may be taken as a constant doctrinal theory of the corporate firm.

The writers adjusted the Angell and Ames formula as corporate doctrine changed. For example, the late nineteenth century texts tended to drop the immortality point. Unlimited corporate life, pre-

164. Bouvier's Law Dictionary 318 (7th ed. 1857); George Field, Private Corporations 1-4 (1877) (Kyd and Marshall variants); 1 Platr Potter, Treatise on the Law of Corporations 1-4 (1879); 1 C. Beach, supra note 82, at 3-4 (1891); 1 Carl Spel.ling, Law of Private Corporations 3-4 (1892); Henry Taylor, Law of Private Corporations (3d ed. 1894); William Clark, Handbook of the Law of Corporations 4-5 (1897) (Kent variant); William Wilson CoOK, A Treatise on the Law of Corporations (4th ed. 1898) (Marshall variant and cases); Herbert Marcus Adler, A Summary of the Law Relating to Corporations 1-4 (1903) (Kyd variant); Leslie Tompkins, A Summary of the Law of Private Corporations 6 (1904) (Kent, Marshall, and Kyd variants); Richard HaRvey, A Handbook of Corporation law 7-8 (1906); Jon T. Mulligan, Law of Corporations 7 (1913); Joseph France, Principles of Corporation Law 3-4 (2d ed. 1914); Isaac Wormser, Law of Private Corporations 3-4 (1921); James Treat Carter, The Nature of the Corporation as a Legal EnTity $37-38$ (1919) (Doctoral thesis, Johns Hopkins Univ.) (Marshall, Kyd, and Kent variants); Charles B. Elliott, The Law of Private Corporations (5th ed. 1923) (Kyd and Marshall variants); Henry Winthrop Ballantine, Ballantine's Manual of Corporation LaW ANd Practice 6 (1930) (Kyd and Marshall variants); William Crow, Formal Corporate Practice (1931) (Marshall variant); Black's Law Dictionary 438 (3d ed. 1933) (Kyd and Marshall variants).

165. 1 Howard Oleck, Modern Corporation LaW $\S 2$ (1958). 
sumably, had become an unremarkable doctrinal assumption. ${ }^{166}$ The late nineteenth century texts also mentioned the decline of concession theory and the passing of the fiction notion. One writer did this even as he cited Chief Justice Marshall with approval for the rest of his firm conception. ${ }^{167}$ Another writer, making the same point about concession and fiction, indicated a preference for Kyd. ${ }^{168}$ Late nineteenth century writers also took the trouble to note explicitly that the received definition renders the corporation as an entity and an aggregate both. ${ }^{169}$ One writer expressed dissatisfaction with the theoretical untidiness of the simultaneous presence of both concepts, accusing Angell and Ames of being contradictory and incorrect. That writer then admitted that practice required continued sufferance of this theoretical contradiction. ${ }^{170}$

Modifications continued after the turn of the century. Writers included the governance model of the liberal incorporation statutes next to the historical definitions. This move provided the reified entity with some additional substance, but otherwise left the Angell and Ames conceptions unchanged. ${ }^{171}$ In his 1913 treatise, Wormser offered an effective and modern reformulation of the Angell and Ames combination. He rendered entity, aggregate, concession, and individual initiative concepts in one clean sentence: "In the last analysis it would seem most accurate to define a corporation as a group of persons authorized by sovereign authority to act as a legal unit."172

The historical definitions also figured into the debates over realism and contractualism. The leading participants in the debate, Freund for corporate realism and Morawetz for contractualism, both commented on them, finding Kyd's definition preferable. Although none of the definitions offered Freund any authority for the realism point, he found Kyd's antipositivism useful as authority refuting the fiction and concession notions. Freund commented that Kyd substitutes a conception of collective capacity. Morawetz preferred Kyd's definition for its aggregateness as well as its antipositivism. Morawetz objected to Chief Justice Marshall's emphasis on fiction and concession notions, and also his entity thinking. To Morawetz the corporation was a fiction, but not the "fiction" of Chief Justice Marshall's conception. Rather, the corporation's rights and duties were those of the persons composing it and not

166. I C. Spelling, supra note 164 , at $3-4$.

167. Id.

168. $1 \mathrm{C}$. BEACH, supra note 82 , at 3-4.

169. Id.; H. TAYLOR, supra note 82 , at 15.

170. H. TAYLOR, supra note 82 , at 15 n.1. Taylor puts Kent and Blackstone on the entity side, and lines up Kyd with Jay Gould, who wrote on the subject. Id.

171. J. Mulligan, supra note 164 , at 7.

172. I. Wormser, supra note 164, at 4; see also J. Muldigan, supra note 164, at 7 (defining a corporation as "a collection of many individuals, united into one body, having perpetual succession under an artificial form, and vested by virtue of the law ... with capacity of acting in many respects as an individual"). 
those of a separate entity. ${ }^{173}$

Moderate commentators who tried to establish positions in the debate between the extremes presented by Freund and Morawetz drew on the historical definitions as well. The definitions supported practical balancing of the entity and aggregate concepts through which some reality could be ascribed to the entity without denial of the individual contribution. ${ }^{174}$

After the turn of the century, writers began to lose confidence in the Angell and Ames definition's effectiveness. The nineteenth century emphases on fiction and concession had disappeared, but no new concepts came in to replace them and limit the definition's capacity. Rather than reformulate from the ground up on some new theoretical basis, writers supplemented the definition with a practical admonition. As one writer said: "A full and complete definition of a corporation can only be given by telling what are its rights, powers, duties, and relations, and the legal and equitable principles which control it in all its parts and functions and how they operate." 175 Hohfeld went farther in this direction. Parting company with the historical definitions, he described the corporation as an association of natural persons conducting business under legal forms, methods, and procedures. ${ }^{176}$ This characterization dispensed with entity and aggregate theorizing and directed attention to doctrinal devices without looking further into them for meaning. These practical definitions, by referring inquiries to particulars of corporate law, said in effect that the legal corporation is the sum of the laws, and that the received theoretical characterizations of the whole lack something in meaning. They thus anticipated Dewey's indeterminacy assertion of twenty to thirty years later.

\section{The Doctrinal Theory of the Corporate Firm After 1930}

Theory of the firm had a bad reputation after the realist/anti-realist debate terminated in the late 1920s. Dewey's indeterminacy assertion became conventional wisdom. ${ }^{177}$ By 1976 , traditional theory of the firm concepts had fallen so far from view that theoretically ambitious works on corporate structure omitted any mention of them. ${ }^{178}$ Discus-

173. V. MORAWETZ, supra note 82 , at $1-2$. Morawetz's legal fiction is roughly the same concept as that of the new economic theorists. See note 3 supra.

174. I C. BEACH, supra note 82, at 3-4; J. CARTER, supra note 164, at 34-38. Kyd's definition, of course, did not support ascription of spiritual reality to the corporation.

175. 1 C. Spelling, supra note 164, at 4; see also Maurice Condit Cross, Types of BusiNESS ENTERPRISE 53 (1928); R. HARVEY, supra note 164, at 7-8; 1 L. TOMPKINS, supra note 164, at 6 .

176. Wesley Newcomb Hohfeld, Fundamental Legal Conceptions 198 (W. Cook ed. 1923); C. ElliotT, supra note 164, at 2.

177. See text accompanying notes 91-93 supra.

178. M. EISENBERG, supra note 132, at 1 (The "general principles underpinning the legal structure of the corporation have not been well articulated.").

One contemporary anti-managerialist writer advocates returning to an entity conception of the corporation in the corporate governance discourse. See Robert L. Knauss, Corporate 
sion shifted to policy inquiries into management performance. Bayless Manning characterized the situation with a flourish in 1962: Commercial images of the corporation had overshadowed the concept of the corporation; corporate law's underlying intellectual construct had rotted away. ${ }^{179}$ Manning correctly identified the dominance of "commercial images" of the corporation even as he overstated the latter point.

Treatise writers after Dewey, freed from transcendental "corporate realism," practiced the very different lessons of "legal realism." They deprecated historical theory of the firm concepts as outmoded "conceptual approaches" to policy problems. ${ }^{180}$ They avoided the whole bundle of past concepts. They even denied the relevance of an entity concept, ${ }^{181}$ debunking it as metaphor, a device for ease of reference. ${ }^{182}$

These writers employed various substitute concepts, all of which had an antecedent in Hohfeld. One concept described the corporation as "more nearly a method than a thing"183 - a "technique" for organizing relationships among individuals. ${ }^{184}$ This approach stripped the fixed content from the entity concept, causing the entity to devolve into a rope tying together the bundle of relationships. Under this approach, each corporate relationship, whether a contract, or performance of a duty stemming from positive law, was analyzed separately according to its own circumstances. The corporation emerged with a variable meaning.

A second substitute was Wormser's "legal unit."185 Here again, the corporation was described as a device-the means to the end of distinguishing corporate rights and liabilities from those of associated individuals. A third substitute was the "group interest." Here the corporation appeared as a "body of [individual] bodies" in which group and individual interests were to be distinguished. ${ }^{186}$ This conception replaced the "entity" with the "group." One writer claimed that this replacement caused all the conceptual difficulties presented by the corporation's nonphysical qualities to disappear. ${ }^{187}$

Governance-A Moving Target, 79 Mrch. L. Rev. 478, 487 (1981). Knauss's point rests on a correct doctrinal assumption: Entity views and duties of care and loyalty go together. But in a climate in which the entity concept is suspect one does better to go beneath it. Instead of exalting the bald reification, one should assert that the care and loyalty duties spring from the constituting parts of the relations that give rise to the entity concept. See Bratton, supra note 17, at

179. Bayless Manning, The Shareholders'Appraisal Remedy: An Essay for Frank Coker, 72 Y ALE L.J. 223, 245 (1962).

180. A. CONARD, supra note 151 , at $419-20$.

181. Walter H. Anderson, Limttations of the Corporate Entrty 7 (1931); Henry Winthrop Ballantine, Ballantine on Corporations 2 (rev. ed. 1946).

182. H. BaLlantine, supra note 181 , at 2 .

183. W. ANDERSON, supra note 181, at 7.

184. David L. Ratner, Corporations and the Constitution, 15 U.S.F. L. REv. 11, 12 (1980-81).

185. H. BallantiNe, supra note 181 , at 2-3 (but not attributing the concept to Wormser).

186. Harry G. Henn, Handbook of the law of Corporations 88 (1961).

187. R. Stevens, supra note 70 , at 51 .

We find another approach in 1 George D. Hornstein, Corporation Law and Practice 
Despite different terminology and modes of legal analysis, and despite assertive repudiation of past conceptions, these "modern" reformulations in the end only recreated the historical definitions' picture of the firm. Gone, of course, were corporate realism and fiction theory. But the historical definition never incorporated the former, and it dropped the latter prior to the turn of the century. Consciousness of the concept's indeterminacy may have been new, but the historical definitions had effectively recognized the inevitability of indeterminacy all along. They built indeterminacy into the doctrine by providing for situational application of the entity and aggregate concepts. The twentieth century writers only repeated this basic lesson when they insisted that the corporation be treated as a person, unit, entity, or group, depending on the context. ${ }^{188}$

The twentieth century writers' various characterizations of the firm entity-group interests, binding methods, and legal units-give us more or less the corporate entity envisioned by Kyd and respected in the treatises for a century. ${ }^{189}$ Even Chief Justice Marshall can be read back into the modern writers. When they pointed out that corporations are merely means to an end, ${ }^{190}$ they only repeated one of the Chief Justice's points. Putting aside the concession notions peculiar to his time, Chief Justice Marshall's legal fiction is difficult to distinguish from the legal unit of the Ballantine treatise. ${ }^{191}$ Both existed for the conduct of business; both were private; both were reified; and both gained meaning in the wider context of corporate doctrine.

\section{COMMENTS FROM THE History}

Drawing on the foregoing historical accounts, this part comments critically on the principal contemporary assertions about the legal theory of the firm.

Horwitz's proposition that corporate realism was a determinative force in legitimizing the management corporation is addressed first. Horwitz does not take into account the doctrinal theory of the firm emphasized in this article. The discussion suggests that once the perspective opens up to encompass the doctrinal theory and its constant quality, Horwitz's point must be modified substantially.

Second, attention turns to the new economic theorists' assertion

2 (1959). In Hornstein's practice-oriented view, what matters is not theory, but whether business people use one form rather than another to achieve desired results.

188. R. Stevens, supra note 70 , at 95 ; Ratner, supra note 184 , at 11,13 (recognizing that the Supreme Court had been flexible all along).

189. W. ANDERSON, supra note 181 , at $7-8$, in fact, admits the existence of the corporate entity even as he formulates an alternative description of it.

190. H. Ballantine, supra note 181 , at 2; Norman D. LatTin, The Law of CorporaTroNs 1 -2 (2d ed. 1971).

191. Ballantine described the corporation as a legal unit with separate legal existence, status and capacity, existing as a device for carrying on business. H. BALLANTINE, supra note 181 , at 2. 
that the corporation "is contract." The discussion suggests that this point is unsuited to literal transfer from the narrow context of economic theory to the wider, more complex context of legal doctrine.

\section{A. Horwitz's Proposition}

Horwitz is right in asserting that corporate realism and the management corporation rose together. Corporate realism certainly offered a collectivist justification for the new mass producing entities. Moreover, it appeared just as these entities worked past the hostile implications of classical economic concepts to secure a safe place in the harbor of corporate law. Implications of mutual assistance arise from such temporal confluences of theory and practice.

But Horwitz's point that corporate realism caused the management corporation's success can be turned around-the practice could have aided the theory more than the theory aided the practice. A counter picture of practice determining theory finds support in the relationships between economic changes at the turn of the century and the several levels of the theory of the corporate firm-the constant doctrinal theory, the opposed schools of corporate realism and contractualism, and superseding managerialist theory. The counter picture is neither more nor less falsifiable than Horwitz's picture.

First consider the relationship between the doctrinal theory of the firm and the development of the management corporation. The management corporation changed the landscape that the corporate treatises described. The definitions reflected the change, albeit indirectly. The late nineteenth century writers omitted the legal fiction concept. This omission had a doctrinal cause-the appearance of general incorporation laws-but it also may be inferred that the management corporation made the theory untenable. The legal fiction notion instantiated the classical economic perspective. Given the management corporation, more in the way of social reality had to be conceded to the firm. The historical definitions made this concession by dropping the limiting concept.

Next consider the relationship between the doctrinal theory of the firm and the debate over corporate realism and contractualism. Here the treatise-writers made a significant move. As the concession and fiction notions dropped out, the contractual and realist schools invited the doctrine in different directions. One offered contract and pure liberal individualism; the other offered realism and European organicism. The doctrinalists refused both invitations, choosing instead, as their predecessors had done, to balance the metapolitical alternatives. The doctrinal theory only changed in appearance when the writers abandoned the historical vocabulary around 1930. This change occurred just after corporate realism collapsed and at the same time that managerialism became the basis for discussion of the management cor- 
poration. Policy replaced doctrine as the mode of debate on corporate legitimacy, and the treatise-writers made conforming changes in their basic conceptions of the corporation.

Thus, when the managerialist era arrived, neither corporate realism nor contractualism had achieved a sufficiently deep level of acceptance to become the generally accepted basis for everyday corporate doctrine. Realism and contractualism were events of primarily academic interest. When academic theory changed course around 1930, corporate realism disappeared with hardly a trace.

The fragility of theory of the firm concepts permits the inference that practice had the primary causative role. The new management corporation necessitated considerable adjustment to ways of thinking about economic life. ${ }^{192}$ It took some time before a settled bundle of concepts achieved general currency. The corporate realism debates occurred during the period of adjustment. Observers were generally favorable to the management corporation because of its apparent economic success, but lacked present explanatory and legitimizing theories. This uncertainty made corporate realism plausible for a time, but the realist explanation proved tentative. As the management corporation matured, a more suitable set of concepts achieved general currency. As a result, corporate realism fell out of currency rather abruptly.

The supplanting and enduring ideas came from contemporary American economics rather than from nineteenth century European jurisprudence. These ideas were practical: Management possessed expertise and performed its job effectively; therefore, it had the law's support. ${ }^{193}$ To the extent management's performance failed to fit whatever scheme of social, political, or economic guidelines the particular observer applied, then some economic or legal adjustment was required. ${ }^{194}$ As this practical picture of the management corporation was drawn, and pro- and anti-managerial positions staked out within its framework, corporate realism's basis in European speculation about group imperatives must have come to seem out of touch with practice.

Ever-present American individualism provides a deeper explanation for the change. Americans historically tend to be uncomfortable with theories-here termed "organicist"-that accord the group intrinsic primacy over the individual. ${ }^{195}$ Corporate realism was organicist; managerialism was not, even though it tended to socialize individual

192. See text accompanying notes 76-80 supra.

193. See notes 116-121 supra and accompanying text.

194. See notes 131-134 supra and accompanying text.

195. See Roberta Romano, Metapolitics and Corporate Law Reform, 36 Stan. L. Rev. 923, 929-30, 934 (1984); see also Bratton, supra note 17, at . Organicist rhetoric never disappears entirely, however. For a recent example, see Oliver E. Williamson, The Logic of Economic Organization, 4 J.L. ECON. \& ORG. 65, 86 (1988) (describing the contemporary corporate restructuring movement as organizational "mitosis," a "quasi-biological" process). 
interests. Managerialism internalized individualism by conditioning its legitimization of collective corporate life on management performance. It acknowledged a significant, if not dominant, place for contract in the structure of the management corporation. ${ }^{196}$ And it offered a firm conception consonant with the political alignment sought by both sides of the debate: With managerialism, individualists could be pro-managerialist at the same time that collectivists could be anti-managerialist.

\section{B. The New Economic Theory of the Firm}

The new economic theory presented something new to the world of neoclassical microeconomics when its neoclassical variant appeared in the 1970s. Its nexus of contracts assertion solved a century-old problem by offering a way around the conceptual barriers to a neoclassical theory of corporate structure. But transposed to a legal context, the assertion was less new than it looked. Contract always has figured into the legal theory of the firm. The new economic theory confirms and repeats legal history when it asserts that the corporation "is contract." It joins a tradition when it offers to resolve the tension between the ideals of classical economics and the institution of the management corporation. But the new theory also breaks with the historical pattern: It is absolutely contractual, while contract never has dominated legal theory.

This absolute contractualism makes problematic the new theory's practical application in the law. The new theory faces the same dilemma as much contemporary academic legal theory. It was received successfully into legal discourse because of its connection to the values that historically have informed corporate law. But this enhancement of historical values continues only so long as the discourse stays on a theoretical level. If the new economic theory were to achieve practical acceptance and become the basis of corporate doctrine, it would reconstruct the earlier values. Thus, the basis for its original acceptance would dissolve in the wake of its complete success.

To see the connection between historical values and the new economic theory's reception in the legal academy, one must take a broad view of the contemporary theoretical landscape. Two steps must be taken for this large picture to come into focus. First, juxtapose the two variants of the new economic theory with the managerialist picture of hierarchical structure. Second, consider the entire theoretical landscape: Managerialist, institutionalist, and neoclassical conceptions coexist in contemporary corporate discourse. Taken together, these conceptions resemble the juxtaposition of conceptions in Angell and Ames. Like the Angell and Ames pictures, these pictures variously emphasize the entity and the aggregate, the sovereign and the contractual. Like Angell and Ames's pictures, all of these view the corporation as a

196. See text accompanying note 198 infra. 
reification, differing in the conceptions placed inside it. The broad view, then, shows a level at which the historical doctrinal theory continues to operate.

Significantly, modern academic theory reflected the doctrinal theory less clearly before the new economic theory appeared. The managerialist picture understated the presence of contract, particularly armslength contract, in corporate arrangements. For decades, antimanagerialist commentators criticized corporate doctrine for insufficient recognition of fiduciary constraints. Not all observers shared this anti-managerialism, but supporters of managerial discretion had no well-articulated theoretical response. The new economic theory's contractualism gave them an answer, explaining and justifying the doctrine's pro-management recalcitrance. It thereby brought academic theory back into alignment with the doctrinal theory and its enduring base point of individualism.

The new theory also resonated well because it drew on elements already present in and around corporate doctrine. Twentieth century corporations and corporate doctrine offered plenty of contracts around which to base a theory. The case law alternated between an entitybased structural conception in which the entity employs management, and a contractually based structural conception, in which management acts as the shareholders' agent. ${ }^{197}$ The Berlian theoretical picture of the corporation featured contract prominently: ${ }^{198}$ Managers, laborers, suppliers, creditors, and customers contracted into corporate relationships; corporate investors traded stocks and bonds by means of discrete contracts. No generally accepted doctrinal barrier had forced the theoretical subordination of contract, at least in the twentieth century. In addition, American jurisprudence had the individualist spirit requisite for a contractual theory.

Thus, the new theory articulated points and values already embedded in the doctrine but only faintly recognized in earlier academic theory. But the new theory broke sharply with another, equally significant strand of historical precedent: the relegation of contract to a supporting role in corporate legal theory and practice. Absolutely asserted contractual theories had appeared before-one during the late nineteenth century and a second with Coase's essay of 1937. Nineteenth century contract theory failed to garner general acceptance, and Coase's 1937 discussion of the firm as a product of cost-effective contracting had limited influence, even among economists, for more than thirty years.

The new economic theory descends directly from Coase. It has a

197. The entity conception is employed, for example, in A. BERLE \& G. MEANS, supra note 60 , at 220-23; R. STEVENs, supra note 70, at 691-92. For an example of the interplay between entity and contractual approaches, see M. EISENBERG, supra note 132, at 85-94.

198. Kaufman \& Zacharias, supra note 51, pointed this out recently. See notes 104-108 supra and accompanying text. 
more collateral relation with the contractualism of nineteenth century legal theory, but a cognizable tie binds the two. Fixing the new theory's relations with earlier corporate theory, and explaining the earlier theory's failure to achieve general acceptance, demonstrates limitations on the new theory's potential practical influence.

The new economic theory's tie to nineteenth century contractualism arises from their common ancestry in the classical economic tradition. The theories bear significant familial resemblances: Both strip the entity reification of nearly all content; both use the phrase "legal fiction" to describe the entity; ${ }^{199}$ both view the relations of managers and corporations in terms of the problems of self-interested agents; ${ }^{200}$ and both utilize the contract idea to forestall governmental restraint of the corporation. ${ }^{201}$

Despite these similarities, the two approaches have materially different goals. The nineteenth century contractualists sought to protect a disaggregated economic system from the constraints of corporate hierarchies. The new economic theory abandons their goal even as it revives their concepts. The new theory accepts the management corporation and employs classical economic ideas-ideas originally derived from observation of a disaggregated economy-to justify its continuing presence.

This is a significant turn in the history of relations between corporate enterprise and American individualism. Before the turn of the century, individualists held to an atomistic social ideal and attacked all big organizations, public and private. Next came an uneasy coexistence, manifested in the neoclassicists' limited consideration of the firm. Finally, with the new economic theory, the heirs of the classical tradition surrender to the corporate hierarchy and embrace it. In so doing, the new theorists announce that corporate hierarchies had been composed of bilateral market contracts all along. But theirs is a different, more rearguard political action than that of their nineteenth century predecessors. Today's contractualists limit their critique to the largest hierarchical institution, the government. To bolster opposition, they legitimize nongovernmental institutions with a diluted version of the atomistic social ideal. ${ }^{202}$

\footnotetext{
199. See text accompanying note 4 supra.

200. See J. Hurst, supra note 54 , at $45-49$ (the nineteenth century critique).

201. This was the move made by the Santa Clara litigants. See text accompanying note 84 supra.

202. Anti-individualist perspectives have gone through twists of their own during this century in their application to corporations. At the turn of the century, the theorists concentrating on group existence were the realists, and their work favored management. In today's corporate law discussions, anti-managerialists take entities most seriously. See text accompanying notes 129-135 supra. Actually, the point is more complex. Early twentieth century Progressives also took group existence seriously, and they opposed the corporate realists. See Horwitz, supra note 14, at 223-24. Post-war institutional economists take corporate entities very seriously on management's behalf. See notes 114-118 supra and accompanying text. The
} 
To explain contract's long absence from academic theories of the corporate firm, we look to the appearance of power relationships in practice. Before the 1970 s, legal academics and institutional economists emphasized hierarchies, while neoclassical economists turned a blind eye to the firm's interior, because contract, and particularly the discrete contract of academic contract law of this century's early decades, ${ }^{203}$ did not seem to capture the institution's essence. The contracting process had a quiet dynamic; it did not appear actively to govern. Management seemed to be the catalyst that made the factors of production work successfully in the management corporation, and this catalytic capability stemmed from structural position. Management appeared to possess unilateral power-it directed production. The obvious complex of bilateral contracts in and around the firm failed to comprise the center of gravity in the theory because they did not seem to affect the distribution of power in practice.

Had actors in the capital markets chosen to exercise a governance role, as they did during the middle period of the nineteenth century, the complex of contracts respecting stocks and bonds might have prompted formulation of a different, more contractual theory of the firm. Instead, a contractual event in practice-the implicit agreement between management and the financial community-kept investors and their stock and bond sales contracts from figuring actively in the power picture. Given this background, the anti-managerialists quite sensibly looked to public sources-the force of public opinion ${ }^{204}$ or legal reform ${ }^{205}$-for controls on management discretion.

Recent practical changes, subsumed under the heading "market for corporate control," have changed the corporate power picture. Stockholders and their contracts have taken a prominent place. ${ }^{206}$ But the changes have not been sufficiently revolutionary to create a practice that mirrors the absolute contractualism held out by the new economic theory.

Anything being possible, the new theory's absolutist contractualism could find its way into corporate doctrine and effect a break with the historical pattern. But given past experience, such a fundamental change seems unlikely. In the past, theories that would close off the capacity of corporate law to facilitate transactions or their regulation have not made the transfer from commentary into doctrine. Singleminded adherence to the new economic theory is as out of touch with

institutionalist new theorists also take group existence seriously, even though they privilege the individual participant's role.

203. This is the formal, objectified contract law of Williston and the first RESTATEMENT OF Contracts (1932).

204. A. BERLE, supra note 20 , at 54 .

205. See Cary, supra note 26; R. Nader, M. Green \& J. Seligman, supra note 20, at 62-65, suggesting federal intervention.

206. These changes are discussed in detail at notes 208-214 infra and accompanying text. 
the values historically undergirding corporate law as some of the singleminded anti-managerialism of the 1970s was in its time.

To sum up, the doctrinal theory of the corporate firm refutes the assertion that the corporation "is contract." History tells us that the corporation "is contract, and always has been contract and other things besides." While the doctrinal theory always takes cognizance of contractual elements, it never makes contract the essence. The doctrinal theory balances contract against the corporate entity and a sovereign presence. If, as seems probable, corporate law continues to evolve in accordance with the historical pattern, decisionmaking will proceed with reference to the particulars of the corporate relationship in question. Selection of the applicable theoretical paradigm-managerialist or contractual-will occur in the particular context as a quasi-political decision. Contractual notions will be entertained, but any move to foreclose wider discussion by the assertion that contract should govern as a function of the intrinsic nature of the corporation will fail.

\section{Contemporary History-The Market for Corporate Control, the Management Corporation, and the NeW ECONOMIC THEORY}

The preceding discussion focused on recent changes in the theories describing power relationships in management corporations. Practical changes in these power relationships also have occurred recently. After 1960 , corporate control became a more and more aggressively traded commodity. After 1980, trading became so extensive that it precipitated a widespread restructuring of management corporations. ${ }^{207}$

A substantial body of commentary connects these practical developments to the new economic theory. The commentators look to the new theory to explain the practice, and to the practice to prove or disprove the new theory's assertions. These connections tend to be ahistorical.

The following discussion connects the theory and the practice on a different level. It considers the practice, in history, as an explanation for the existence of the theory, and the theory, in history, as an explanation for changes in the practice.

\section{A. The Early Market for Corporate Control and the Appearance of the New Economic Theory}

As discussed in part IV, practical appearances of hierarchical power kept contract in a supporting role in corporate theory during most of this century. The market for corporate control has changed the practical picture materially. The hostile takeover makes it possible to remove corporate superiors by the exercise of stock market purchasing power. As takeovers have proliferated, changes have followed in the structure

207. See notes 215-221 infra and accompanying text. 
and internal affairs of management hierarchies. In effect, discrete contracts among stockholders take a significant place in the governance of the management corporation for the first time. The new economic theory parallels this practical change: It brings discrete contracting to a significant theoretical place in the governance of the management corporation for the first time. The histories of the theory and the practice invite interrelation.

Here is the proposition: The appearance of this aggressive mode of discrete contracting was necessary to make a contractual picture of the management corporation plausible. Although the new economic theory, particularly its neoclassical variant, tends to be stated ahistorically, its success, and possibly its very existence, meaningfully can be accounted for historically. Had the practical changes not occurred, the new theory probably never would have appeared, and it certainly would not have achieved general currency in the legal academy. ${ }^{208}$

The chronology of the market for corporate control supports the proposition. Tender offers have a long history as a corporate tool, but prior to the 1950s they were used internally as a mode of stock repurchase. The earliest hostile uses of the tender offer came in the 1950s, and this usage matured in the 1960s. The first intensive year was 1963, in which twenty-three hostile tender offers were made; eighty-six tender offers were made in 1967. Most of these early hostile tender offers were successful. ${ }^{209}$ Neoclassical observers saw the tie to their methodology right away. Henry Manne made the first theoretical assertion that the takeover phenomenon constituted market control of management conduct in an article published in 1965..$^{210}$ He introduced the phrase "market for corporate control" and asserted that the market accorded shareholders practical power commensurate with their interests in the corporation.

Manne's neoclassical interpretation was not the only plausible view of the takeover phenomenon during the early period. Indeed, prior to 1980 , Manne's probably was not the most widely accepted view. The early takeovers also fit into the institutional economists' picture. In their view, the takeover enhanced managerial power. The paradigm

208. One caveat should be entered here. While practice in this context facilitated the emergence of new theory by raising practical questions about the accuracy of the received managerialist picture, the theorists did not necessarily make primary reference to the practice. The neoclassical variant of the new economic theory draws heavily on neoclassical microeconomic assumptions. The classical market ideal from which these assumptions are drawn has been largely superseded in history. The theory's adherence to these assumptions attenuates its connection to practice.

209. Douglas V. Austin, Tender Offers Revisited: 1968-1972 Comparisons with the Past and Future Trends, 8 Mergers \& AcQuisitions, Fall 1973, at 16. The number of tender offers declined in the early 1970 s and then picked up again in the middle of that decade. Douglas V. Austin, Tender Offer Statistics: New Strategies Are Paying Off, 10 Mergers \& Acquismons, Fall 1975 , at $9,10-11$.

210. Henry G. Manne, Mergers and the Market for Corporate Control, 73 J. PoL. Econ. 110 , 113 (1965). 
hostile takeover during the 1960s and 1970s was an aggressive act by the managers of a large corporation against the managers of a smaller corporation. This paradigm takeover was one of several means employed in building conglomerate corporations. Such takeovers served the managerialist growth objective. Although the managers of the losing target corporation lost their jobs, their removal came at the initiative of a more powerful, similarly situated group. Management's image of structural empowerment therefore remained in place even as some insecurity of tenure came into the picture. ${ }^{211}$

Williamson, writing in accord with this perspective, explained the appearance of takeovers after 1960 as a product of the spread of the multidivisional corporate structure. This new structure redirected management attention from running production lines to the collection of conglomerate portfolios of operating units. Takeovers then arose to facilitate portfolio construction. ${ }^{212}$

During the early takeover period, lawyers and legal academics, like most economists, continued to operate under the managerialist picture. Anti-managerialists viewed management growth by acquisition with suspicion. Most of this suspicion manifested itself in antitrust objections, but corporate law reasons for caution also existed. Antimanagerialists sought application of fiduciary duty concepts to restrain the conduct of management in defending against tender offers, and to protect the interests of minority shareholders after takeover. ${ }^{213}$ Furthermore, hostile takeovers tended to depress the price of the stock of the successful offeror, showing a market judgment that the takeovers aggrandized the managers of offeror corporations, and enriched target shareholders at the expense of the offeror's shareholders. ${ }^{214}$

211. The takeover "threat" also was considered a market mechanism for discipline of management conduct. It accordingly provided a response to the anti-managerialists' legitimacy point. See M. Aokr, supra note 110 , at 36-40.

212. Focusing on multidivisional structure reconstituted the firm as a governance structure rather than a production function. Williamson, supra note 49, at 362; see also Williamson, The Modern Corporation: Origins, Evolution, and Altributes, supra note 42.

213. Heavily criticized decisions permitting defensive tactics include: Panter v. Marshall Field \& Co., 646 F.2d 271 (7th Cir. 1981); Moran v. Household Int'l, Inc., 500 A.2d 1346 (Del. 1985); Cheff v. Mathes, 41 Del. Ch. 494, 199 A.2d 548 (1964). Recently, the courts have begun to scrutinize more closely management decisions regarding the control market. See Revlon, Inc. v. MacAndrews \& Forbes Holdings, Inc., 506 A.2d 173 (Del. 1986); Hanson Trust PLC v. ML SCM Acquisition, Inc., 781 F.2d 264 (2d Cir. 1986).

In cases concerning the treatment of minority shareholder interests remaining in the acquired corporation after a takeover, the Delaware courts have made some famous anti-managerial rulings. See Weinberger v. UOP, Inc., 457 A.2d 701 (Del. 1983); Singer v. Magnavox Co., 380 A.2d 969 (Del. 1977).

214. Herman, supra note 117, at 537; Paul H. Malatesta, The Wealth Effects of Merger Activity and the Objective Functions of Merging Firms, $11 \mathrm{~J}$. FIN. ECON. 155, 177 (1983). Contra Michael C. Jensen \& Richard S. Ruback, The Market for Corporate Control: The Scientific Evidence, 11 J. Fin. ECON. 5, 11, 16 (1983). 


\section{B. The Contemporary Market for Corporate Control and the New Economic Theory}

The new economic theory does not unequivocally support management interests. The theory's denial of hierarchy strengthens management's position, but only as long as it does not support any serious challenges to that position. During the 1980 s, the market for corporate control created such challenges. Just as the new economic theory's contractualism supports management against statist challenges from the corporate governance movement, its contractualism also supports corporate control transactions against management objections. ${ }^{215}$

In the more aggressive market for corporate control that appeared after 1980, almost all corporations became potential subjects for attack. Trading extended to corporate reconstruction as well as corporate control. Even middle management began to suffer. In this new cast, the takeover challenged not only management's security of position, but also its discretionary power.

New actors and financing devices carried the market to this more aggressive posture. Independent financial entrepreneurs entered the market as hostile offerors. ${ }^{216}$ The new entrepreneurs played a different game. Unlike the conglomerate-building managers of the earlier period, they did not use the devices of the corporate control market to enhance operational power positions. They simply sought to force large payments to equity holders.

Funds for the big premiums came through aggressive use of the oldest financing tool, debt. The target's assets supplied the borrowing base. Once target-based debt financing became a critical component in a tender offer's success, a structural position atop a corporate hierarchy ceased to be a prerequisite for participation in the market. An actor taking an aggressive posture needed only credibility in the capital markets.

"Bust up" takeovers commenced in 1984. These opened up a second source of finance-sale of the target company's assets. Big payments to equity holders came from the proceeds of a subsequent dismantling of the target corporation as well as from borrowing. With these takeovers, actors on the corporate control market began to deconstruct the conglomerate corporations that the early control mar-

215. The theory's agency cost line comes to bear against management here. The tender offer is conceived as a traditional form of market control. It encourages devotion to the principal's interest in the agent. This idea can be traced to Manne, supra note 210 , at 112-14, and it reappears frequently in the contemporary literature on takeovers. See, e.g., Lucian A. Bebchuck, The Case for Facilitating Competing Tender Offers, 95 HaRv. L. Rev. 1028, 1030-31 (1982); Frank H. Easterbrook \& Daniel R. Fischel, The Proper Role of a Target's .Management in Responding to a Tender Offer, 94 HARv. L. REv. 1161, 1169-74 (1981); Ronald J. Gilson, A Structural Approach to Corporations: The Case Against Defensive Tactics in Tender Offers, 33 STAN. L. Rev. 819,841 (1981).

216. John C. Coffee, Jr., Shareholders Versus Managers: The Strain in the Corporate Web, 85 MrCH. L. REv. 1, 2-3 (1986). 
ket helped construct. Reconstruction also was pursued defensively, through leveraged buyouts and stock repurchases. These defensive payouts to equity holders utilized the same financing tools of borrowing and asset sales. ${ }^{217}$

Although the full implications of this corporate restructuring remain unclear, a few generalizations can be made. The restructurings materially alter the old managerialist picture of structural empowerment. First, their quantity, scope, and frequency has made management tenure generally insecure. Second, the longstanding implicit agreement between management and capital has dissolved. The investment community no longer passively accepts the growth objective. Thus, restructurings may be viewed as the capital markets' successful demand for the return of capital suboptimally invested in pursuit of growth. ${ }^{218}$ By forcing the return of this capital, the investment community indirectly, but strongly, influences the shaping of investment policy. Because investment policy is the central discretionary function of the multidivisional corporate management group, capital's refusal to comply and cooperate denudes management of significant power.

For the first time since the brief appearance of finance capitalism in the nineteenth century, ${ }^{219}$ then, actors in the capital markets critically influence investment policy. Capital's perspective still tends toward the short term. As a result, conflicts between the short- and long-term investment perspectives of investors and managers have become a problem once again. ${ }^{220}$ Legal policy discussions have adjusted in response. Emphasis has shifted from management's abuse of power acquired by structural default, to management's inability to invest with a long view because of capital's power to terminate management at will. ${ }^{221}$

The restructurings also require conforming adjustments in the existing body of work under the new economic theory. The institutionalists explained the conglomerate corporation as a product of a contracting process driven by the competitive need to decrease costs. ${ }^{222}$ The restructurings undo conglomerate combinations, eliminating layers of multidivisional form diversification and firing layers of management staff. ${ }^{223}$ In effect, the financial community repudiates the

217. Of the 850 largest American corporations, 398 undertook voluntary restructurings between the beginning of 1984 and the middle of 1985 . Id. at 7 .

218. That is, the capital was invested in the corporation for a return at a rate less than its cost. There is statistical evidence that excessive earnings retention, a practice detrimental to shareholders, was common. See id. at $22 \&$ n.59.

219. See text accompanying note 69 supra.

220. See generally Louis Lowenstein, What's Wrong with Wall Street (1988).

221. The contemporary discussions are well summarized in several articles in a BusinEss WEEK special report entitled Deal Mania. See Norman Jonas \& Joan Berger, Do all these Deals Help or Hurt the L'.S. Economy, Bus. WK., Nov. 24, 1986, at 86-88; Judith H. Dobrzynski, More than Ever, I's . Uanagement for the Short Term, Bus. WK. Nov. 24, 1986, at 92-93.

222. See notes 99-100 supra and accompanying text.

223. This is Coffee's critique of Williamson. See Coffee, supra note 216, at 31-35. Williamson has responded by updating his historical account of the evolution of corporate organ- 
proposition that conglomerates are cost effective.

The neoclassical model ${ }^{224}$ also must be adjusted. ${ }^{225}$ The model assumed that contracting actors adopted structures capable of bringing agency costs down to a competitive minimum. It then explained existing arrangements, including the relative passivity of the capital markets and the dominance of management, in those terms. When historical forces suddenly and materially rewrote the contracts, doubts arose about the validity of this ahistorical picture, and of the methodology that created it. The restructurings manifest the capital markets' judgment that previous market arrangements did not effectively minimize management agency costs. In response, Jensen has modified his picture of the firm to explain the massive replacement of equity by debt in terms of an efficient contracting device: Management borrows at a high fixed rate to "bond" its future performance. ${ }^{226}$ But, as Coffee has pointed out, this prospective and ahistorical adjustment does not erase the model's previous failure to accommodate history. ${ }^{227}$

Despite these difficulties with particulars, the new economic theory may be connected with the appearance of the market for corporate reconstruction. To see the connection one must take a broad view. The new theory's contractual perspective assumes that people look closely and act firmly when money is at stake. It depicts a corporate structure in which rational investors work hard to circumvent managerial claims to nonreviewability due to differential expertise. ${ }^{228}$ This approach consigns management to a reduced status.

ization. He accounts for restructuring as an outgrowth of the spread of the modern conglomerate structure. Because the benefits from an acquisition may not continue indefinitely, the M-form entity undergoes "mitosis"-a "quasi-biological" process likened to cell division in which the firm divests acquired activities, often in multidivisional units which are themselves M-form firms. Williamson, supra note 195 , at 86-87.

224. See text accompanying notes $28-40$ supra.

225. This discussion draws extensively on Coffee, supra note 216 , at 25-28.

226. Michael C. Jensen, Agency Costs of Free Cash Flow, Corporate Finance and Takeovers, 76 AM. Econ. Rev. 323, 324-26 (May 1986) (papers \& proceedings).

227. Coffee, supra note 216 , at 28.

228. Levmore, supra note 22 , at 70-72. Levmore, working within the paradigm, anticipated the interacting elements of later restructurings. He noted that shareholder and management interests diverge when the shareholder interest calls for dissolution of the corporation. He applied an institutionalist explanation: Management had made a firm-specific investment; a shutdown would be contrary to its interest in recouping that investment. Id. at 71 .

Levmore also noted a pertinent problem with the Jensen and Meckling model of the firm. In their model, management, by increasing its own stake in the enterprise, decreased its incentive to misbehave and the investors' need to monitor, thereby reducing agency costs. Drawing on finance theory, Levmore noted that management's investment interests also include a diversified portfolio, and that this interest would prevent it from making such an extensive investment in its own firm. Id. at 67.

Coffee has expanded on these points in an explanation of the bust-up takeover. Coffee sees management through the lens of finance theory and contends that management's inevitably outsized investment in its own firm makes rational diversification of its portfolio impossible. Management therefore is more risk averse than are investors in the financial community who can and do fully diversify their investment portfolios. As a result, management makes safe investments which are suboptimal from the point of view of investors. The current wave 
The neoclassical picture contains additional, strong negative implications for management. The theory's minimal firm entity removes management from its former position as the essence of the firm. Management emerges in the picture as but one of many factors of production. ${ }^{229}$ In the neoclassical world of discrete contracts, factors of production come and go as contracts continually are made, performed, and remade, or are made and broken. No relational values afford management a defense against attack by investors seeking to rewrite the next generation of contracts. No entity notions, no notion of professionalism, and no sense of the necessity of tenure protection enter into the picture.

Even the institutional variant implicitly recognizes managerial vulnerability. Its description of multidivisional structure demystifies the management process. Hands-on production skills no longer figure into management's strategic position. The multidivisional architect of a portfolio of operating divisions has no skills not possessed in rudimentary form by the latest crop of business school graduates. Like the neoclassicists' factors of production, the institutionalists' portfolio manager is replaceable in the active search for a higher return. ${ }^{230}$

Thus, the market practice of corporate restructuring generated by contract-sales of stock on or off the trading markets, and arms-length debt contracts ${ }^{231}$-demonstrates the theory's dynamic, if not every point of the extant models. The market practice follows the theory in time: In the 1970s, the theory asserted that the managerialist picture of unilateral power was inaccurate; in the $1980 \mathrm{~s}$, the marketplace changed the picture and used the theory's primary tool, the discrete, bilateral contract, as the means of shifting power. Today's popular conception of the powerful business figure is not the managerialist chief executive officer but the capitalist deal maker-the financial entrepreneur or the investment banker. ${ }^{232}$ Characterized in the vocabulary of the new eco-

of corporate restructurings are an assertion by the investment community of the primacy of its own investment objectives. See Coffee, supra note 216, at 15-21.

229. See Eugene F. Fama, Agency Problems and the Theory of the Firm, 88 J. Por. EcoN. 288, 290 (1980) (describing management as a "type of labor but with a special role-coordinating the activities of inputs and carrying out the contracts agreed [upon] among [the] inputs").

230. Viewed retrospectively, management's invocation of the authority of the new economic theorists in the corporate governance debates of the early 1980 s was precipitous. See notes 142-143 supra and accompanying text. The notions of entity and sovereign participation undergirding the anti-managerialist arguments contain much more defensive potential than does the new theory's contractualism. A comparison of the Delaware cases on tender offer defense tactics dramatically illustrates this point. The successful case incorporates protection of the entity. See Cheff v. Mathes, 41 Del. Ch. 494, 199 A.2d 548 (1964). The management group that abandons an entity conception and reconstitutes its responses with contractual values weakens its case. See Revlon v. MacAndrews \& Forbes Holdings, Inc., 506 A.2d 173 (Del. 1986).

231. For a review of changes in debt contracting patterns, see Morey W. McDaniel, Bondholders and Corporate Governance, 41 Bus. Law. 413 (1986).

232. See Anthony Bianco, America Has a New Kingpin: the Investment Banker, Bus. Wr., Nov. 24, 1986, at 77. The character Gordon Gekko in the film Wall Street manifests the conception. 
nomic theory, these figures acquire power as transaction cost engineers. They conceive and initiate transactions, depriving the managerial beneficiaries of the more costly existing contracts of power and wealth.

Can we ascribe to the antecedent theory a causative role in the subsequent practice? Paraphrasing Horwitz's conclusions on the turn-ofthe-century interplay between theory of the firm and corporate practice, the causation assertion would be that the rise of the new economic theory was a "major factor" in legitimizing the market restructuring of the management corporation and that "none of the theoretical alternatives could provide as much sustenance" 233 to the new anti-management utilization of the market for corporate control.

This causation assertion overstates the theory's role. Conceptual associations between the theory and the practice are easy to make; articulating a precise causative role for the theory in recent movements of billions of dollars of capital is more difficult. Models in the Journal of Financial Economics do not become business plans for the new financial entrepreneurs. Moreover, practice offers alternative, plausible determinative antecedents. Two decades of managerialist use of the takeover account for the presence of the devices used. The contemporary structure of the institutional investment community accounts for the disappearance of the Wall Street rule and for more aggressive shareholder postures. The competitive failures of American management in international markets during the last two decades, ${ }^{234}$ and the disappointing returns on common stock during the decade prior to 1984 , account for a general consensus on the need to restructure.

Even so, the new economic theory has a place in all this. The restructuring takeover has met little effective opposition, ${ }^{235}$ and any number of legislative moves might have deterred it. ${ }^{236}$ The theory persuasively manifests the wider antiregulatory and contractualist environ-

233. Horwitz, supra note 14 , at 176 .

234. See generally M. Prore \& C. SABEL, supra note 74, at 184-202.

235. For criticism of congressional inaction, see L. LowENSTEIN, supra note 220 , at 156 58, 168-76. Talk of congressional intervention persists, fueled by the stock market crash of October 1987, and the great food company restructurings of the fall of 1988 . Intervention itself still seems unlikely. See Gregory Robb, Ruder Sees No Crisis in Buyouts, N.Y. Times, Dec. 23, 1988, at D1, col. 3; see generally William W. Bratton, Corporate Debt Relationships: Legal Theory in a Time of Restructuring, 1989 DukE L.J. 92.

The exception to the rule of nonintervention is the proliferation of state takeover statutes. These have gone through several generations of form and have been the subject of two Supreme Court opinions. Edgar v. Mite Corp., 457 U.S. 624 (1982) (statute requiring disclosure by offeror beyond that required by federal law unconstitutionally burdens interstate commerce); CTS Corp. v. Dynamics Corp. of America, 481 U.S. 69 (1987) (sustaining statute conditioning offeror's privilege to vote its shares on the approval of other shareholders); sce Arthur R. Pinto, Takeover Statutes: The Dormanl Commerce Clause and State Corporate Law, $41 \mathrm{U}$. Miami L. Rev. 473 (1987). Here again, despite a lot of sound and fury, takeover activity does not seem to have been discouraged materially.

236. For a recent manifestation of the new economic thinking, consider David Ruder, then the nominee for Chairman of the Securities and Exchange Commission, telling Congress that the benefits to the shareholders of takeover premiums outweigh loss of employment and 
ment in a respectable academic form specific to the context. The neoclassical variant, with its roots in classical economic theory, comes particularly well-made to support moneymaking by independent entrepreneurs through bilateral contracting.

Significantly, corporate legal doctrine performs a similar legitimizing role. The doctrine, despite its close association with managerialism throughout this century, has accommodated the resurgent capitalists without significant alteration. The received structure incorporates bilateral contracting and aggregate interests. The doctrine made available all of the contractual devices employed in the restructuring market, and the long-standing conceptual association of management and the corporate entity did not prevent their use. ${ }^{237}$ Even as the restructuring takeover brought the continued validity of reams of managerialist literature into question, it left the doctrine nearly untouched. ${ }^{238}$ The historical doctrinal theory of the firm and its facilitative and capacious qualities come to mind, providing the new economic theory with a "place" in the legitimization of the recent restructuring.

\section{Comments}

The restructuring takeover does not return us to the world of Adam Smith. The number of managerial personnel may have declined; their identities may have changed; and conglomerate corporations may have become less bloated. But they still exist. Management retains a position of "power by default." Its basic operational authority over resources and people in the organization remains largely intact. ${ }^{239}$ Restructuring takeovers do not threaten the hierarchy; they only replace one set of managers with another. And aside from single rounds

other disruptions of the local community. See Nathaniel Nash, A Hands-Off Takeover Stance, N.Y. Times, July 23, 1987, at DI, col. 3 .

Congress only recently began seriously to consider additional procedural barriers to tender offers. See Proxmire to Offer Bill to Require Prenotification of Bidders' Purchases, BNA's CoRP. Couns. WeEkLy, Apr. 15, 1987, at 1.

237. One of the strongest examples of corporate law's continuing conceptual association of management and the corporate entity is that management is permitted to engage in self-defense in the name of the entity. See note 213 supra. That these defense tactics have had only limited success shows the constant power of contract.

238. Some of the alterations protect management. See note 235 supra (discussing state anti-takeover statutes).

Other developments result in intensified judicial scrutiny under the rubric of fiduciary duty. The old management expertise rationale carries less weight when the decisionmaking context is that of the sale of the entire company. In these transactional contexts, courts feel more comfortable with close review for self-interested decisions. See, e.g., Revlon, Inc. v. MacAndrews \& Forbes Holdings, Inc., 506 A.2d 173 (Del. 1986); Smith v. Van Gorkom, 488 A.2d 858 (Del. 1985).

239. Changes are beginning to appear here also, as management organization structures become looser and more flexible in emerging industries. See Michael J. Piore, Corporate Reform in American Manufacturing and the Challenge to Economic Theory (paper presented at the conference on Economics of Organization at the Yale School of Organization and Management, October 24-25, 1986) (on file with the Stanford Law Review). 
of cost cutting, no creative interplay between the restructuring takeover and the production operations of the firm has appeared.

Assume that a chastened and more heavily monitored management emerges with its position otherwise left intact. It can, ironically, turn to contractualism to reconstruct a theory of the firm protective of its position. Legal theory offers more than one model of contract. Theories more relational than that employed by the neoclassical new theorists offer values protective of individuals who invest their labor and energies in business enterprises, including firms. ${ }^{240}$

\section{ConClusion}

This article's historical perspectives do not deny the legitimacy of the new economic theory's approach to corporations. Nor do these perspectives deny that contract holds a constitutive place in firm life or that the new economic theory isolates significant aspects of corporate relationships. By contextualizing this theory of the firm discourse in time, however, these perspectives do facilitate a more accurate appraisal of the new economic theory's contribution. The history prompts doubts as to the theorists' extreme essentialist claims: Their new corporate contract becomes hard to accept either as an evolutionary climax or as an objectively correct edifice standing outside of time. Instead, the theory appears as an edifice partly built on enduring ontology, partly prompted by recent, perhaps transitory, trends in corporate practice, and partly shaped by the theorists' political dispositions.

These historical perspectives, it should be noted, do not support discrimination among theories of the firm. They do not single out the new economic theory for critical questioning. Instead, they counsel wariness of essentialist claims made for any academic theory of the firm. The history shows us that the pairs of opposing concepts that make up theories of the firm-entity and aggregate, contract and concession, public and private, discrete contract and relational contract-endure in opposition over time. Academic firm theories and corporate legal doctrine tend to handle these internal conflicts differently. Doctrinal firm theory lacks analytical integrity; the opposing concepts are synchronized as decisionmakers make normative responses to unfolding events in business practice. If recognition of one of these contradictions results in analytical paralysis in a specific case, the doctrinalists deny the contradiction, mentioning one side only. Despite this lack of integrity, the doctrinal theory works well as it operates at close quarters with economic practice. Rather than trying to privilege one or another contradictory element, it builds the contradictions into a capacious structure

240. See Bratton, supra note 17, at . For an early example of contractual managerialism, see Coffee's suggestion of sharing of takeover gains, or "premium sharing." Coffee, supra note 216 , at 12. Coffee proposes a conception of corporate structure in which management and shareholders share the position of residual risk bearer and residual beneficiary. Id. 
that loosely contains real-world producing organizations. This legal structure accommodates economic change easily.

Practice also drives academic firm theory. But in an academic context, a theory that follows the doctrine and merely synchronizes contradictions in particular situations probably falls short of prevailing standards. Academics, free of the immediate problem of deciding cases, try to achieve analytical consistency; they attempt to transcend the contradictions. Academic theory of the firm, created in pursuit of this objective, has a more volatile, evolutionary pattern than does doctrinal theory. One tends to have to overstate things in order to achieve consistency and at the same time remain in touch with practice in a complex world. Wariness therefore is appropriate in considering new academic theories that purport to explain existing doctrine and at the same time satisfy academic standards. Such theories may have more reconstructive potential than their progenitors admit.

The new economic theory falls into this historical pattern of academic/doctrinal interplay. Introduced in the law as a critical supplement to managerialist theory, it succeeded because it recognized discrete contract as a constitutive part of firms. The recent appearance of discrete contract as an important corporate power tool made the theory especially welcome: It brought academic theory closer both to business practice and to legal doctrine. But the theorists, driven by the academic need to universalize, outstripped this ontological base by privileging narrow notions of contract.

Pressure builds up as the new theory's paradigm approaches hegemony in legal academic discussion. Some structure of thought will have to change. Two possible scenarios present themselves. Under one, the doctrine is reconstructed. The theory's influence causes the doctrine to be reformulated to eradicate strains that contradict the theory. Under the other scenario, the theory adapts. The contract paradigm expands to encompass the range of conflicting firm components. Given the history, the second scenario seems the more likely to occur. Doctrinal reconstruction tends to occur in response to practical, not theoretical, developments, legitimizing or inhibiting them as the case may be. Actors who create corporate law have shown little disposition to reconstitute it as a means to the end of recognition of the latest academic theory. 
